\title{
RNA-seq of muscle from pigs divergent in feed efficiency and product quality identifies differences in immune response, growth, and macronutrient and connective tissue metabolism
}

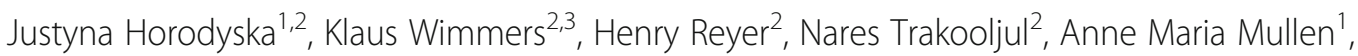
Peadar G. Lawlor ${ }^{4}$ and Ruth M. Hamill ${ }^{1 *}$ (D)

\begin{abstract}
Background: Feed efficiency (FE) is an indicator of efficiency in converting energy and nutrients from feed into a tissue that is of major environmental and economic significance. The molecular mechanisms contributing to differences in FE are not fully elucidated, therefore the objective of this study was to profile the porcine Longissimus thoracis et lumborum (LTL) muscle transcriptome, examine the product quality from pigs divergent in FE and investigate the functional networks underpinning the potential relationship between product quality and FE.

Results: RNA-Seq $(n=16)$ and product quality $(n=40)$ analysis were carried out in the LTL of pigs differing in FE status. A total of 272 annotated genes were differentially expressed with a $P<0.01$. Functional annotation revealed a number of biological events related to immune response, growth, carbohydrate \& lipid metabolism and connective tissue indicating that these might be the key mechanisms governing differences in FE. Five most significant bio-functions altered in FE groups were 'haematological system development \& function', 'lymphoid tissue structure \& development', 'tissue morphology', 'cellular movement' and 'immune cell trafficking'. Top significant canonical pathways represented among the differentially expressed genes included 'IL-8 signalling', 'leukocyte extravasation signalling, 'sphingosine-1-phosphate signalling', 'PKCO signalling in T lymphocytes' and 'fMLP signalling in neutrophils'. A minor impairment in the quality of meat, in relation to texture and water-holding capacity, produced by high-FE pigs was observed. High-FE pigs also had reduced intramuscular fat content and improved nutritional profile in terms of fatty acid composition.

Conclusions: Ontology analysis revealed enhanced activity of adaptive immunity and phagocytes in high-FE pigs suggesting more efficient conserving of resources, which can be utilised for other important biological processes. Shifts in carbohydrate conversion into glucose in FE-divergent muscle may underpin the divergent evolution of pH profile in meat from the FE-groups. Moreover, altered amino acid metabolism and increased mobilisation \& flux of calcium may influence growth in FE-divergent muscle. Furthermore, decreased degradation of fibroblasts in FE-divergent muscle could impact on collagen turnover and alter tenderness of meat, whilst enhanced lipid degradation in high-FE pigs may potentially underlie a more efficient fat metabolism in these animals.
\end{abstract}

Keywords: FE, RFI, Residual feed intake, Gene expression, Transcriptomics, RNA

\footnotetext{
* Correspondence: Ruth.Hamill@teagasc.ie

${ }^{1}$ Teagasc, Food Research Centre, Ashtown, Dublin 15, Ireland

Full list of author information is available at the end of the article
}

(c) The Author(s). 2018 Open Access This article is distributed under the terms of the Creative Commons Attribution 4.0 International License (http://creativecommons.org/licenses/by/4.0/) which permits unrestricted use, distribution, and reproduction in any medium, provided you give appropriate credit to the original author(s) and the source, provide a link to the Creative Commons license, and indicate if changes were made. The Creative Commons Public Domain Dedication waiver (http://creativecommons.org/publicdomain/zero/1.0/) applies to the data made available in this article, unless otherwise stated. 


\section{Background}

Pork consumption accounts for over 36 percent of the world's meat intake [1]. Porcine muscle is a significant source of high biological value proteins, vitamins and minerals, as well as dietary fats such as saturated fatty acids (SFA), monounsaturated fatty acids (MUFA), polyunsaturated fatty acids (PUFA), cholesterol and triacylglycerol [2]. SFA and cholesterol content, have been linked to obesity, cardiovascular disease and type 2 diabetes mellitus [3, 4], therefore consumers perceive leaner pork, which is lower in these components as a more healthy option $[5,6]$.

Feed efficiency (FE) is an indicator of efficiency in converting energy and nutrients from feed into a tissue that is of major nutritional and economic significance [7]. FE is a complex trait involving many organs and can be influenced by environmental and health related factors $[8,9]$. Skeletal muscle, being the largest organ in the body and an important location of carbohydrate and lipid metabolism [10-12], plays a particularly important role in the utilisation and storage of a large proportion of the energy acquired from feed. Therefore enhancing our understanding of the biological processes occurring in muscle from FE-divergent pigs could optimise the strategies to improving FE and ease the production cost and ecological footprint from pork production. Furthermore, FE has been shown to be associated with product quality and nutritive profile in several studies, with evidence that the muscle of high-FE pigs exhibits reduced adiposity $[13,14]$, lower SFA and MUFA, and an enhanced proportion of PUFA [14], which is known for its protective properties against cardiovascular disease [15], and altered overall product quality $[13,14,16,17]$. Thus divergence in FE is not only of importance to animal production, but it also impacts consumers' preference with regards to quality, nutritive value and wholesomeness of meat.

The molecular mechanisms contributing to differences in FE are not fully elucidated. To date, few studies have conducted transcriptome profiling of skeletal muscle in FE-divergent pigs e.g. [18-20]. Furthermore, these studies did not examine the consequences of divergence in $\mathrm{FE}$ on product quality. Here we investigate the impact of divergence in residual feed intake (RFI; the difference between actual feed intake and predicted feed requirements) on product quality of the porcine Longissimus thoracis et lumborum (LTL) muscle. Furthermore, we identify in that muscle important biological functions and pathways enriched with differentially expressed (DE) genes in relation to FE, and the functional networks underpinning the relationship between product quality and FE.

\section{Results}

Differential gene expression profile

An average of 104.4 million high quality paired-end reads per sample were mapped to the reference with a mean of $80.9 \%$ mapping efficiency. A total of 14,497 genes were expressed in the muscle (Fig. 1) and of these 306 (272 annotated) genes were differentially expressed between high- and low-FE samples with a $P<0.01$ corresponding to false discovery rate $(q) \leq 0.47$. Of these annotated genes, 176 were up- and 96 were down-regulated, whilst 140 were found to be at least 1.5-fold differentially expressed in high- versus low-FE pigs (Additional file 1: Table S1). The most altered genes were TREH (fold change $=4.49$; high-FE $>$ low-FE) and SDC4 (fold change $=-2.35$; high-FE $<$ low-FE). Transcripts with a $P<0.01$ corresponding to a $\mathrm{q} \leq 0.47$ were considered significantly differentially expressed, which is not a highly stringent cut-off because the differences in mRNA abundances between the FE groups were relatively small. However to offset this lower statistical stringency for differential expression profiling, B-H corrected p-values were used to refine the data that was further utilised to extract bio-functions, pathways and networks.

\section{Gene ontology analysis}

Enrichment analysis of the DE genes was utilised to investigate biological processes and pathways altered in response to differences in FE. Thirty nine biological functions and thirty eight canonical pathways were significantly $(P<0.01)$ enriched with DE genes. Most affected biological functions were 'haematological system development \& function', 'lymphoid tissue structure \& development', 'tissue morphology', 'cellular movement' and 'immune cell trafficking' (Table 1). A list of sub-categories enclosed within each function is presented in Additional file 2: Table S2. A number of functions ranged from significantly repressed to significantly activated state, including 'haematological system development and function' ( $\mathrm{z}$-score range: $-2.13-3.52$ ), 'tissue morphology' (z-score range: $-2.13-2.87$ ) and 'cell death and survival' (z-score range: -2.27 - 2.20). Functions containing a positive $z$-score range included immune cell trafficking' (z-score range: 0.58 - 3.52), cell-to-cell signalling and interaction' (z-score range: $0.12-3.19$ ), cell-mediated immune response' (z-score range: 0.58 2.94), 'tissue development' (z-score range: $0.78-2.30$ ) and 'vitamin and mineral metabolism' (z-score range: 2.36 - 2.89). Furthermore, most affected pathways were 'IL-8 signalling', 'leukocyte extravasation signalling', 'sphingosine-1-phosphate signalling, 'PKC $\theta$ signalling in $\mathrm{T}$ lymphocytes' and 'fMLP signalling in neutrophils' (Table 2 and Additional file 3: Table S3). Analysis of molecule connectivity revealed nineteen networks enriched with DE genes, of which network \#2 (Fig. 2) contained 21 DE molecules related to macronutrients metabolism, specifically 'protein synthesis,' lipid metabolism' and 'molecular transport'. 


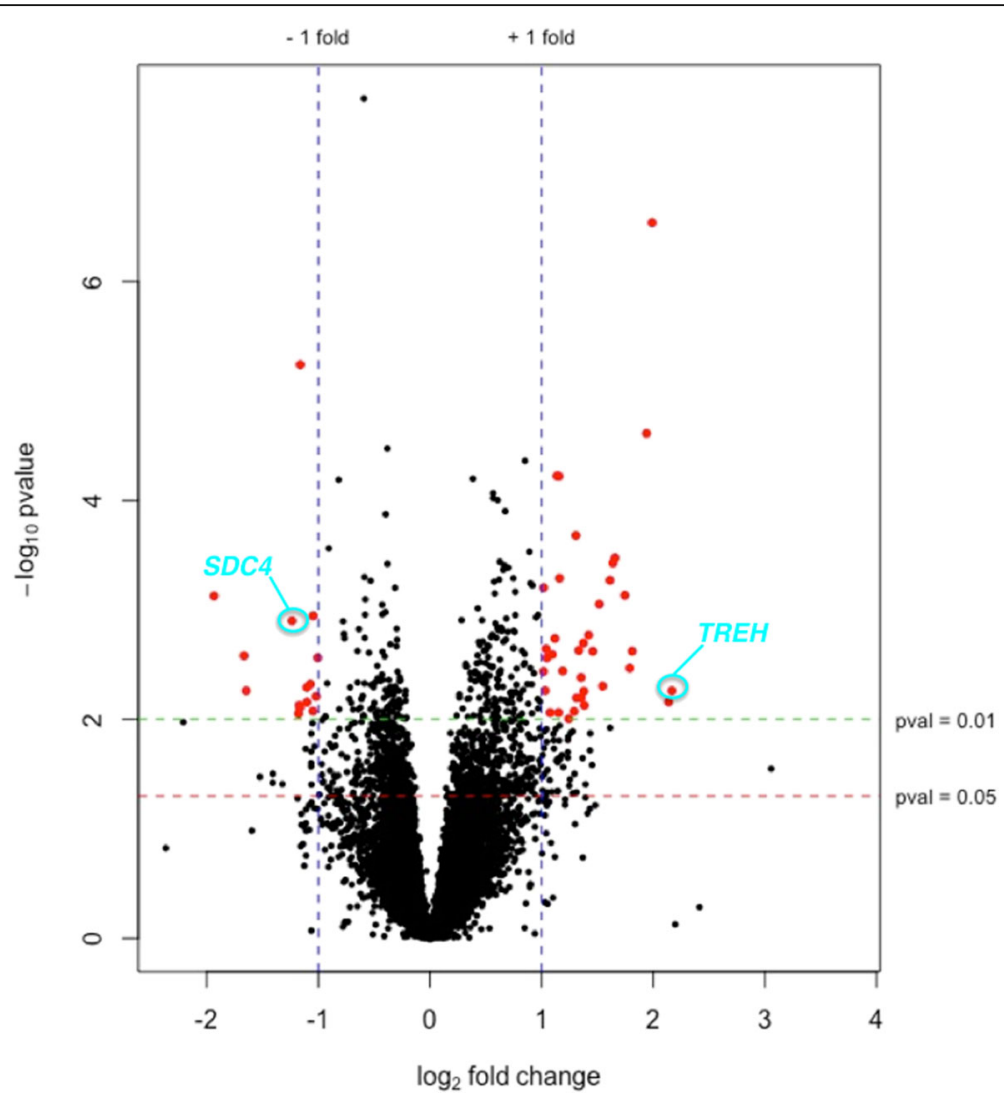

Fig. 1 Volcano plot depicting a total of 14,497 genes expressed in muscle from pigs divergent in feed efficiency. The horizontal green and red lines indicate the suggestive significance thresholds of differentially expressed (DE) genes at $P<0.01$ and 0.05 , respectively. The vertical blue lines represent the threshold of log 2 fold change $\geq|1|$ (fold change $\geq|2|$ ) and the red dots depict significantly DE genes at $P<0.01$ and log 2 fold change $\geq|1|$ (fold change $\geq|2|$ ). Positive and negative fold changes refer to up- and down-regulated genes in high-FE pigs, respectively. The most up- and down-regulated annotated genes are highlighted in a circle

\section{Validation of RNA-seq results}

Expression patterns of thirteen genes (FAM134B, FOXO1, SPP1, TRIM63, CASP1, COL11A1, CYBB, ITGB2, MYC, PLCB2, SDC4, TREH and VCAM1), which were selected randomly and also as representatives of the canonical pathways altered by feed efficiency, were confirmed through qPCR. RPL10 and RPL32 were utilised as reference genes to normalise expressions of these target transcripts. Significant differences in the mRNA abundances of FAM134B, FOXO1, TRIM63, COL11A1, CYBB, MYC, PLCB2, SDC4, TREH and $V C A M 1$ transcripts between the FE groups were verified. Moreover, CASP1 and ITGB2 exhibited a $P<0.1$. Spearman correlations between RNA-seq and qPCR data, ranging from 0.509 to 0.950 , were significant for all thirteen assessed mRNAs (Table 3).

\section{Product quality}

Carcass and product quality traits of FE-divergent pigs are depicted in Table 4, whereby sensory attributes of LTL muscle in FE-divergent pigs are illustrated in Fig. 3. Intramuscular fat (IMF) content significantly differed between the FE groups $(P<0.05)$, with the high-FE carcasses having leaner muscle (1.49\% IMF) comparing to low-FE carcasses (1.89\% IMF). Muscle depth and percent lean meat did not differ significantly between the $\mathrm{FE}$ groups however $\mathrm{pH}$ at $45 \mathrm{~min}$ post-mortem (pm) showed a tendency toward decreased values in the high-FE pigs $(P<0.1)$ while $\mathrm{pH}$ measured at $2 \mathrm{~h}, 3 \mathrm{~h}, 4 \mathrm{~h}$, $5 \mathrm{~h}$ and $24 \mathrm{~h} \mathrm{pm}$ was significantly lower in the high-FE group $(P<0.05)$, and changes in $\mathrm{pH}$ evolution over time are depicted in Fig. 4. Drip loss did not vary between the FE groups. Muscle from high-FE pigs had increased cook loss on day $1 \mathrm{pm}(P<0.01)$ but there was no difference detected on day $7 \mathrm{pm}$. Although meat produced by high-FE pigs was significantly associated with increased Warner Bratzler shear force values (WBSF, less tender) on day $1 \mathrm{pm}(P<0.05)$ and had a tendency towards increased WBSF values on day $7 \mathrm{pm}(P<0.1)$, this difference in tenderness between the FE groups was not detected by sensory panellists. However, pork sensory assessment revealed that meat produced from high-FE pigs had higher scores for salty taste $(P<0.05)$ and a tendency towards increased barny/earthy/animal stable 
Table 1 Molecular, cellular and physiological categories significantly over-represented among the differentially expressed genes

\begin{tabular}{|c|c|c|}
\hline Category & B-H p-value range* & Z-score range \\
\hline $\begin{array}{l}\text { Haematological System } \\
\text { Development \& Function }\end{array}$ & $1.72 \mathrm{E}-11-5.00 \mathrm{E}-03$ & $-2.13-3.52^{b}$ \\
\hline $\begin{array}{l}\text { Lymphoid Tissue Structure \& } \\
\text { Development }\end{array}$ & $1.72 \mathrm{E}-11-5.00 \mathrm{E}-03$ & $-0.65-2.94^{b}$ \\
\hline Tissue Morphology & $1.72 \mathrm{E}-11-5.16 \mathrm{E}-03$ & $-2.13-2.87^{b}$ \\
\hline Cellular Movement & $1.72 \mathrm{E}-11-5.74 \mathrm{E}-03$ & $-0.36-3.52^{b}$ \\
\hline Immune Cell Trafficking & $6.54 \mathrm{E}-11-5.74 \mathrm{E}-03$ & $0.58-3.52^{b}$ \\
\hline Cellular Function \& Maintenance & $6.54 \mathrm{E}-11-4.56 \mathrm{E}-03$ & $-0.06-2.83^{b}$ \\
\hline Cellular Development & $1.29 \mathrm{E}-10-5.00 \mathrm{E}-03$ & $-0.65-1.64$ \\
\hline Cellular Growth \& Proliferation & $1.29 \mathrm{E}-10-5.00 \mathrm{E}-03$ & $-0.65-1.73$ \\
\hline Cell-To-Cell Signalling \& Interaction & $2.21 \mathrm{E}-09-5.74 \mathrm{E}-03$ & $0.12-3.19^{b}$ \\
\hline Protein Synthesis & $6.50 \mathrm{E}-09-2.32 \mathrm{E}-03$ & $0.24-1.18$ \\
\hline Humoral Immune Response & $9.96 \mathrm{E}-09-3.58 \mathrm{E}-03$ & $-0.57-1.89$ \\
\hline Cellular Compromise & $1.14 \mathrm{E}-08-2.80 \mathrm{E}-03$ & $-1.51-2.20^{b}$ \\
\hline Cell-mediated Immune Response & $1.79 \mathrm{E}-07-5.74 \mathrm{E}-03$ & $0.58-2.94^{b}$ \\
\hline Free Radical Scavenging & $2.33 \mathrm{E}-07-8.89 \mathrm{E}-07$ & 1.13 \\
\hline Cell Death \& Survival & $2.42 \mathrm{E}-06-4.57 \mathrm{E}-03$ & $-2.27-2.20^{b}$ \\
\hline Tissue Development & $3.60 \mathrm{E}-06-4.56 \mathrm{E}-03$ & $0.78-2.30^{b}$ \\
\hline Embryonic Development & $5.77 \mathrm{E}-06-3.53 \mathrm{E}-03$ & $0.54-1.50$ \\
\hline Haematopoiesis & $5.77 \mathrm{E}-06-1.11 \mathrm{E}-03$ & $0.78-1.77$ \\
\hline Organ Developr & 5.77E-06 - 3.94E-03 & $-0.66-1.50$ \\
\hline Organismal Development & $5.77 \mathrm{E}-06-4.95 \mathrm{E}-03$ & $0.72-1.64$ \\
\hline Cell Morphology & $1.39 \mathrm{E}-05-4.95 \mathrm{E}-03$ & $-0.08-2.09^{b}$ \\
\hline Lipid Metabolism & $1.48 \mathrm{E}-05-1.19 \mathrm{E}-03$ & $-1.23-0.60$ \\
\hline Small Molecule Biochemistry & $1.48 \mathrm{E}-05-5.74 \mathrm{E}-03$ & $-1.23-0.60$ \\
\hline prphology & $1.70 \mathrm{E}-05-4.95 \mathrm{E}-03$ & $1.06-1.77$ \\
\hline Molecular Transport & $1.97 \mathrm{E}-05-1.81 \mathrm{E}-03$ & $-0.01-2.89^{b}$ \\
\hline $\begin{array}{l}\text { Cardiovascular System } \\
\text { Development \& Function }\end{array}$ & $2.63 \mathrm{E}-05-4.95 \mathrm{E}-03$ & $-0.95-2.12^{b}$ \\
\hline $\begin{array}{l}\text { Digestive System } \\
\text { Development \& Function }\end{array}$ & $6.90 \mathrm{E}-05-5.38 \mathrm{E}-03$ & -0.66 \\
\hline Organismal Survival & 8.09E-05 - 8.09E-05 & -0.04 \\
\hline Cell Signalling & $1.05 \mathrm{E}-04-1.81 \mathrm{E}-03$ & $0.12-3.19^{b}$ \\
\hline Vitamin \& Mineral Metabolism & $1.05 \mathrm{E}-04-1.81 \mathrm{E}-03$ & $2.36-2.89^{b}$ \\
\hline Cell Cycle & $5.91 \mathrm{E}-04-3.94 \mathrm{E}-03$ & $-0.49--1.98$ \\
\hline Gene Expression & $5.91 \mathrm{E}-04-3.53 \mathrm{E}-03$ & $-1.98--0.49$ \\
\hline Cellular Assembly \& Organization & 7.30E-04 - 5.74E-03 & $0.33-1.89$ \\
\hline $\begin{array}{l}\text { Renal \& Urological System } \\
\text { Development \& Function }\end{array}$ & $1.74 \mathrm{E}-03-3.94 \mathrm{E}-03$ & $-0.15-0.76$ \\
\hline Carbohydrate Metabolism & $2.09 \mathrm{E}-03-2.09 \mathrm{E}-03$ & NA \\
\hline Amino Acid Metabolism & $2.74 \mathrm{E}-03-5.74 \mathrm{E}-03$ & NA \\
\hline Hepatic System Development \& & $3.20 \mathrm{E}-03-3.20 \mathrm{E}-03$ & -0.66 \\
\hline
\end{tabular}

Table 1 Molecular, cellular and physiological categories significantly over-represented among the differentially expressed genes (Continued)

\begin{tabular}{lcc}
\hline Category & B-H p-value range* & Z-score range \\
\hline $\begin{array}{l}\text { Skeletal \& Muscular System } \\
\text { Development \& Function }\end{array}$ & $3.54 \mathrm{E}-03-3.54 \mathrm{E}-03$ & NA \\
$\begin{array}{l}\text { Nervous System Development \& } \\
\text { Function }\end{array}$ & $4.63 \mathrm{E}-0-4.63 \mathrm{E}-03$ & $\mathrm{NA}$ \\
\hline
\end{tabular}

*Range of B-H multiple testing correction $p$-values of enriched functions within the category; ${ }^{\text {a }}$ range of $z$-scores for sub-categories contained within a particular category; ${ }^{b}$ annotations with a $z$-score $>2$ and $z$-score $<-2$ were considered significantly activated and inhibited in high-FE pigs, respectively; NA: no activity pattern available

flavour $(P<0.1)$. Nutritive profile in relation to fatty acid (FA) proportions in LTL muscle (mg FA/100g meat), and percentage of FA in IMF of FE-divergent pigs are shown in Fig. 5. SFA did not differ significantly in LTL muscle of FE-divergent pigs, however, a tendency towards decreased proportions for each of palmitic and stearic acids in high-FE muscle was observed $(P<0.1)$. Muscle from high-FE group contained significantly lower amounts of the MUFA, palmitoleic acid $(P<0.05)$ and had a tendency towards decreased proportions of eicosenoic and oleic acids $(P<0.1)$. While PUFA content of muscle did not differ, when comparing the IMF per se, high-FE muscle had significantly greater concentrations of linoleic and alpha-linolenic acids $(P<0.05)$.

Furthermore, a number of significant correlations at a $P<0.05$ were identified between product quality / sensory traits / nutritive value and genes differentially expressed in FE-divergent pigs (Tables 5 and 6). The strongest positive linear relationships were observed between fatty after effect and COL11A1 ( $\mathrm{r}=0.76)$, percentage lean and $H K 3(\mathrm{r}=0.679)$, and cook loss on day 7 pm and PON3 $(\mathrm{r}=0.621)$. The strongest negative linear relationships were observed between cook loss on day 1 pm and NFATC2 ( $\mathrm{r}=-0.809)$, MUFA and HK3 $(\mathrm{r}=$ -0.741), and cook loss on day $1 \mathrm{pm}$ and MYC ( $\mathrm{r}=$ -0.724). Principal component analysis (PCA) revealed that PC-1, PC-2 and PC-3 (Fig. 6a and b) cumulatively accounted for a total of 51 percent of the variation. PC-1, explaining 27 percent of the variation, was driven by our selected measure of FE, residual feed intake (RFI; the difference between actual feed intake and predicted feed requirements) and also captured the variability in certain meat quality traits, including ultimate $\mathrm{pH}$, IMF and cook loss, which were associated with RFI (Fig. 2, Tables 4 and 5). PC-2, accounting for 15 percent of the variation, was not associated with RFI and captured some of the variation related to the product quality traits. As it can be seen in Fig. 6b, close co-locations were noted for WBSF day $7 \mathrm{pm}$ and NAAA, pH 45m, 2h, $5 \mathrm{~h} \mathrm{pm}$ and CAST, $\mathrm{pH} 24 \mathrm{~h} p m$ and ESRRA, $\mathrm{pH} 4 \mathrm{~h}$ $p m$ and PLIN1, cook loss day $1 \mathrm{pm}$ and NDUFS6, drip 
Table 2 Most significant canonical pathways observed among differentially expressed genes in relation to feed efficiency (FE)

\begin{tabular}{|c|c|c|c|}
\hline Canonical Pathway & $-\log (\mathrm{B}-\mathrm{H}$ p-value) & Z-score & Genes \\
\hline IL-8 signalling & 4.13 & $2.50^{\mathrm{a}}$ & $\begin{array}{l}\text { RND2, PIK3C2B, PLCB2, VCAM1, PTK2B, PIK3C2G, GNB5, MAPK8 } \\
\text { RAC3, ROCK2, ITGB2, FGFR4, NCF2, CYBB }\end{array}$ \\
\hline Leukocyte extravasation signalling & 3.38 & 1.73 & $\begin{array}{l}\text { PIK3C2B, VCAM1, PTK2B, CXCR4, PIK3C2G, MAPK8, RAPGEF3, } \\
\text { ROCK2, ITGB2, FGFR4, NCF2, CYBB, VAV1 }\end{array}$ \\
\hline Sphingosine-1-phosphate signalling & 3.38 & 1.67 & $\begin{array}{l}\text { RND2, PIK3C2B, NAAA, PLCB2, PTK2B, FGFR4, ADCY4, PIK3C2G, } \\
\text { SPHK1, CASP1 }\end{array}$ \\
\hline PKC $\theta$ signalling in T lymphocytes & 3.22 & 0.63 & $\begin{array}{l}\text { PIK3C2B, MAP3K14, FGFR4, PIK3C2G, MAPK8, CD86, NFATC2, } \\
\text { VAV1, RAC3, NFATC1 }\end{array}$ \\
\hline fMLP signalling in neutrophils & 2.86 & 1.41 & $\begin{array}{l}\text { PIK3C2B, PLCB2, FGFR4, NCF2, PIK3C2G, CYBB, GNB5, NFATC2, } \\
\text { NFATC1 }\end{array}$ \\
\hline B cell receptor signalling & 2.86 & 0.91 & $\begin{array}{l}\text { PIK3C2B, MAP3K14, FOXO1, PTK2B, FGFR4, PIK3C2G, MAPK8, } \\
\text { NFATC2, VAV1, PIK3AP1, NFATC1 }\end{array}$ \\
\hline Myc mediated apoptosis signalling & 2.86 & NA & MYC, PIK3C2B, FGFR4, PIK3C2G, MAPK8, CYCS, SFN \\
\hline Chemokine signalling & 2.86 & 1.13 & ROCK2, PLCB2, PTK2B, CXCR4, PIK3C2G, MAPK8, CCL5 \\
\hline Gaq signalling & 2.86 & 1.00 & $\begin{array}{l}\text { RND2, ROCK2, PIK3C2B, PLCB2, PTK2B, FGFR4, PIK3C2G, GNB5, } \\
\text { NFATC2, NFATC1 }\end{array}$ \\
\hline CD28 signalling in T helper cells & 2.86 & 0.33 & $\begin{array}{l}\text { PIK3C2B, FGFR4, PIK3C2G, MAPK8, CD86, NFATC2, VAV1, CTLA4, } \\
\text { NFATC1 }\end{array}$ \\
\hline
\end{tabular}

${ }^{a}$ Significantly activated (z-score $>2$ ) pathways in high-FE pigs, NA no activity pattern available, up-regulated genes in high-FE pigs are highlighted in bold and down-regulated genes in normal typeface

loss and FGFR4, as well as lean percentage and VCAM1. Moreover, the biplot revealed a close co-location of a number of sensory attributes with genes i.e., porky aroma and LPCAT2, barny aroma and ETV1, sweet and TRERF1, difficult to swallow and RAPGEF3, stringy and NFATC2 and NFATC2, as well as chewy and CLEC7A.

\section{Discussion}

Functional annotation of divergent genes revealed a number of biological events related to immune response, growth, carbohydrate \& lipid metabolism and connective tissue indicating that these might be important mechanisms governing differences in FE. Alongside attaining insights of the biological processes contributing to differences in muscle of FE-divergent pigs, we also investigated the consequences of the divergence in $\mathrm{FE}$ on product quality and the functional networks within muscle that underpin the relationship between FE and product quality. Divergence in FE affected various aspects of product quality and nutritive value, such as $\mathrm{pH}$, tenderness, cook loss, as well as IMF content and fatty acid proportions, and this study provided clues with regards to biological mechanisms driving the relationship between FE and the observed alteration in product quality traits of economic significance.

\section{Immune response}

Ontology analysis revealed a number of pathways and biological functions related to immune response as being relevant to FE in porcine muscle. Greater amounts of leucocytes [21] and higher cellular immune response
[22], were previously observed in pigs selected for lean growth. In the present study 'protein kinase C-theta (PKC $\theta)$ signalling in T lymphocytes' and 'cluster of differentiation 28 (CD28) signalling in T helper cells', which activate and promote differentiation of $\mathrm{T}$ cells, were significantly enriched cell-mediated immune responses. These features were also observed in pigs selected for lean growth that were subjected to an immunological challenge i.e. tetanus toxoid [22]. Furthermore, 'tec-kinase signalling, involved in development and function of cellular immune response T-cells [23] was significantly activated $(\mathrm{z}$-score $=2.12)$ in high-FE pigs exhibiting leaner growth. This pathway, alongside many other significantly over-represented pathways, was enriched with Phosphatidylinositol-4-Phosphate 3-Kinase Catalytic Subunit Type 2 Beta (PIK3C2B) belonging to a family of enzymes modulating immune cell development, differentiation and function [24]. PIK3C2B was specifically shown to play a key role in T-cell activation [25]. Functional annotation also exposed 'Interleukin 8 (IL-8) signalling', controlling trafficking of neutrophils and macrophages to the site of inflammation [26], to be significantly activated in high-FE pigs $(\mathrm{z}$-score $=2.50)$. 'Accumulation of phagocytes' and 'phagocytosis', contained within the broader 'immune cell trafficking and tissue development' and 'cellular function and maintenance' categories, respectively, were also predicted to be significantly activated in high-FE pigs (z-score $=2.15$ and 2.12, respectively). Additionally pathways playing a role in stimulating phagocytes activity [27] and muscle repair capabilities [28], 'N-formyl-Met-Leu-Phe (fMLP) signalling 


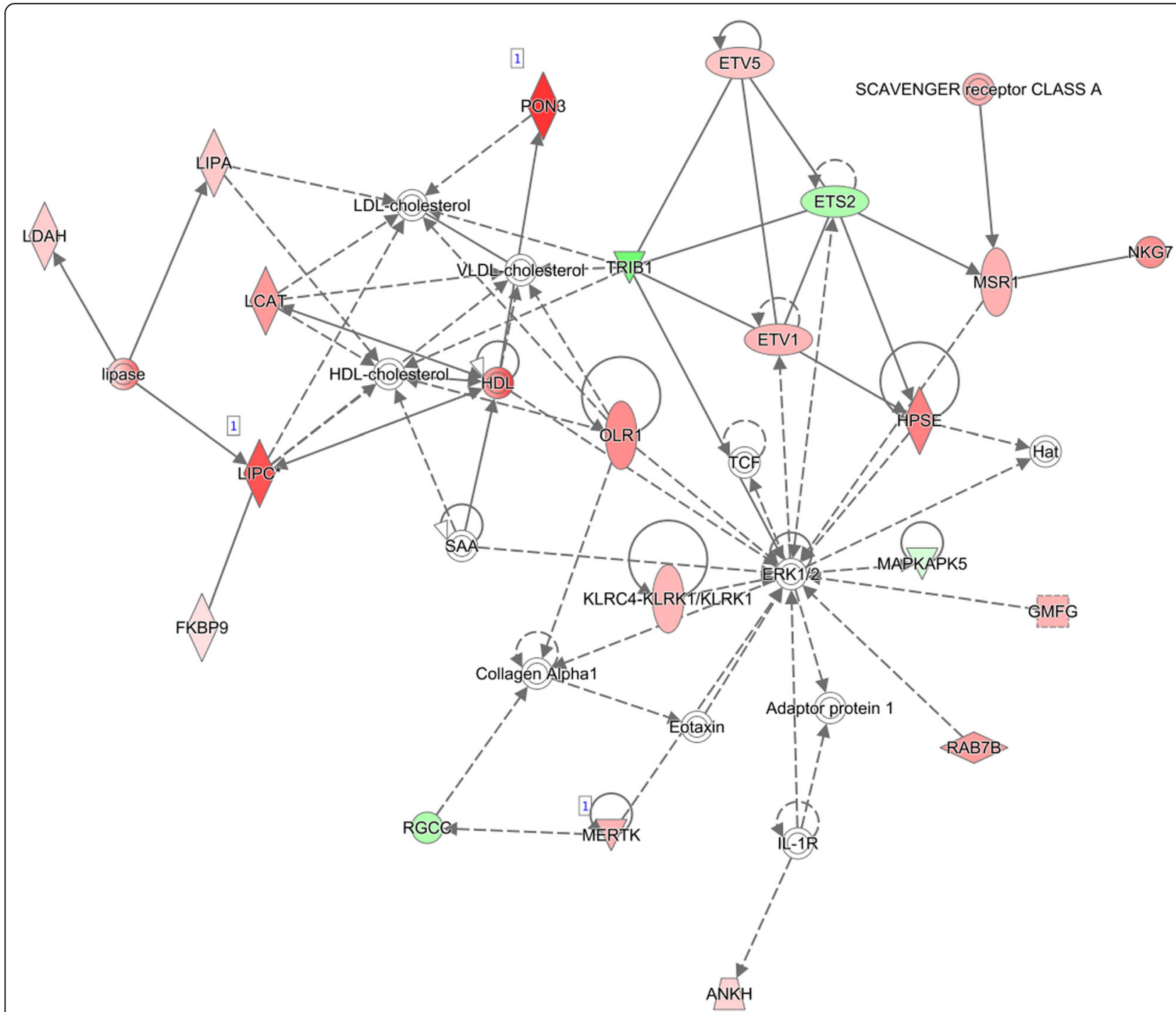

Fig. 2 Network \#2 containing functions related to 'protein synthesis', 'lipid metabolism', and 'molecular transport'. Genes are denoted as nodes and the biological relationship between two nodes is denoted as an edge/line. Node colour represents up- (red) and down- (green) regulated genes in high-FE pigs

in neutrophils' and 'production of nitric oxide in macrophages', tended towards activation in high-FE pigs. Fuelling immune response is an energetically expensive process, which would be suspected to lower animal's feed efficiency due to prioritizing nutrients towards the immune-related processes [8]. Previous literature has reported decreased immune response in muscle from high-FE pigs [18]. On the contrary, a study conducted in cattle identified a number of immune-related processes, representing both innate and adaptive response, significantly activated in muscle of high-FE individuals i.e., 'immune response of antigen presenting cells and leukocytes', 'response of mononuclear leukocytes and myeloid cells', and 'immune response of phagocytes' [29]. Here, our findings suggest that muscle from high-FE pigs exhibit activated immune response. Furthermore, more reliance on adaptive rather than innate immunity, which could reduce feed requirements, may stimulate faster growth of muscle [30] from high-FE pigs.

\section{Carbohydrate metabolism and glycolytic potential}

$\mathrm{pH}$ evolution in the pre-rigor period was highly divergent in relation to FE status. At the earliest time-point measured $(45 \mathrm{~m} \mathrm{pm}), \mathrm{pH}$ did not significantly differ. However, $\mathrm{pH}$ at all later stages in the early $\mathrm{pm}$ periodup to 5 hours- as well as ultimate $\mathrm{pH}$ monitored the next day significantly differed between the two groups, with the high-FE pigs showing decreased $\mathrm{pH}$ values in the muscle. This is consistent with previous studies demonstrating greater glycolytic potential in high-FE 
Table 3 Comparison of RNA-seq and qPCR data of selected genes affected by feed efficiency (FE)

\begin{tabular}{|c|c|c|c|}
\hline Gene & qPCR fold change & RNA-seq fold change & Spearman's rho \\
\hline FAM134B & $2.1^{* *}$ & $2.1^{* *}$ & $0.874^{* * *}$ \\
\hline FOXO1 & $1.6^{* * *}$ & $1.5^{* *}$ & $0.785^{* * *}$ \\
\hline SPP1 & 3.6 & $2.5^{*}$ & $0.950^{* * *}$ \\
\hline TRIM63 & $2.2^{* *}$ & $2.0^{* *}$ & $0.918^{* * *}$ \\
\hline CASP1 & $1.8^{\mathrm{f}}$ & $1.9^{* *}$ & $0.509^{*}$ \\
\hline COL11A1 & $1.8^{*}$ & $1.5^{* *}$ & $0.968^{* * *}$ \\
\hline$C Y B B$ & $1.5^{*}$ & $1.6^{* *}$ & $0.641^{* *}$ \\
\hline ITGB2 & $1.7^{£}$ & $1.5^{*}$ & $0.765^{* *}$ \\
\hline MYC & $-1.5^{*}$ & $-1.6^{* *}$ & $0.947^{* * *}$ \\
\hline PLCB2 & $1.5^{*}$ & $1.7^{* *}$ & $0.612^{*}$ \\
\hline SDC4 & $-2.5^{* * *}$ & $-2.4^{* *}$ & $0.868^{* * *}$ \\
\hline TREH & $3.5^{*}$ & $4.5^{* *}$ & $0.818^{* * *}$ \\
\hline VCAM1 & $1.4^{*}$ & $1.4^{* *}$ & $0.803^{* * *}$ \\
\hline
\end{tabular}

${ }^{\mathrm{E}} P<0.1,{ }^{*} P<0.05,{ }^{*} P<0.01,{ }^{* * *} P<0.001$; up-regulated genes in high-FE pigs are highlighted in bold and down-regulated genes in normal typeface

pigs, wherein $\mathrm{pH} 30 \mathrm{~m} \mathrm{pm}$ did not differ but ultimate $\mathrm{pH}$ was significantly reduced in high-FE pigs $[13,16]$. Low $\mathrm{pH}$ in meat can increase the perception of sour taste due to a higher concentration of free hydrogen ions [31, 32]. Nevertheless, the significant difference in ultimate $\mathrm{pH}$ was not detected as increased acidity by sensory panellists in this study, who perceived no difference in sour taste of meat from high- versus low-FE. However, the reduced ultimate $\mathrm{pH}$ may have contributed to significantly higher scores for 'salty taste' that were observed in high-FE meat. This is in agreement with Lipinski et al. [33] who previously found that meat with lower $\mathrm{pH}$ can be perceived by sensory panellists as more salty.

Genes involved in glycolysis and energy metabolism were previously reported to be up-regulated in chickens exhibiting lower ultimate $\mathrm{pH}$ [34]. Here, $\mathrm{pH}$ evolution

Table 4 Product quality traits of Longissimus thoracis et lumborum muscle divergent in feed efficiency (FE)

\begin{tabular}{lcccc}
\hline Trait & High-FE $^{a}$ & Low-FE $^{a}$ & SE & P-value \\
\hline Fat depth (mm) & 14.6 & 15.5 & 0.95 & 0.364 \\
Muscle depth (mm) & 54.6 & 56.8 & 2.36 & 0.367 \\
Lean (\%) & 56.2 & 55.5 & 0.87 & 0.477 \\
IMF (\%) & 1.49 & 1.89 & 0.19 & 0.046 \\
Drip loss (\%) & 4.71 & 4.16 & 0.68 & 0.428 \\
WBSF day 1 pm (N) & 37.0 & 31.8 & 2.33 & 0.036 \\
WBSF day 7 pm (N) & 28.9 & 26.4 & 1.46 & 0.089 \\
Cook loss day 1 pm (\%) & 36.4 & 34.0 & 0.67 & 0.001 \\
Cook loss day 7 pm (\%) & 37.8 & 37.2 & 0.58 & 0.250 \\
\hline
\end{tabular}

aLeast square means for each trait; ${ }^{\mathrm{b}}$ WBSF Warner Bratzler shear force (higher values indicate decreased tenderness). was significantly different in the FE-divergent muscle, and trehalase (TREH) that codes for an enzyme catalysing the conversion of trehalose to glucose [35] was the most up-regulated gene (fold change $=4.49$ ) in high-FE pigs. This might indicate that this group of pigs could potentially exhibit more efficient energy conversion in growth, but with potential consequences for post-mortem energy metabolism and product quality. In support to this, PCA revealed negative correlations between $T R E H$ and $\mathrm{pH}$ at $45 \mathrm{~m}$ up to $5 \mathrm{~h} p m$, whilst a positive correlation between TREH and the discussed above product saltiness (Fig. 6b). Indeed, ontology analysis highlighted the molecular function 'catabolism of oligosaccharides', which was enclosed within a broader 'carbohydrate metabolism' category, as being highly relevant to the gene expression changes in divergent FE muscle. Moreover genes enriched in this sub-category, GM2 ganglioside activator $(G M 2 A$, fold change $=1.60$; high-FE $>$ low-FE $)$ and neuraminidase 3 (NEU3, fold change $=1.29$; high-FE > low-FE), were negatively correlated with ultimate $\mathrm{pH}$ and positively correlated with drip loss, respectively (Table 5). These findings suggest that differences in carbohydrate conversion into glucose underpin the differential evolution of $\mathrm{pH}$ profile in $\mathrm{FE}$-divergent muscle.

Carbohydrate metabolism has an important influence on water-holding capacity of meat [36]. Water-holding capacity traits, alongside tenderness, are closely linked with $\mathrm{pH}$ and here unfavourable associations between $\mathrm{FE}$, lower ultimate $\mathrm{pH}$ and increased cook loss on day $1 \mathrm{pm}$ with a reduced tenderness (6N increase in WBSF) were observed. However, sensory tenderness remained unchanged and, other than saltiness, no other sensory attributes were altered. It has been previously postulated that lower water-holding capacity of meat with decreased ultimate $\mathrm{pH}$ can result in tougher beef (increased WBSF) [37], which is consistent with our (WBSF) observations in the present study. Another gene that was associated with tenderness and aspects of $\mathrm{pH}$ profile and water-holding capacity was calpastatin $(C A S T)$, the inhibitor of calpain. CAST was closely located to $\mathrm{pH} 45 \mathrm{~m}, 2 \mathrm{~h}$ and $5 \mathrm{~h} \mathrm{pm}$ (Fig. $6 \mathrm{~b}$ ), and this is consistent with its known associations with water-holding capacity in pork [38]. Another potential candidate gene for quality is transcription factor P64 (MYC), which plays a role in apoptosis [39]. In the present study, a correlation analysis (Table 5) demonstrated a negative correlation between $M Y C$ and cook loss on day $1 \mathrm{pm}$ and this is consistent with a previous study which identified a SNP in MYC to be associated with $\mathrm{pH}$ and cook loss in pork [40].

\section{Growth}

Syndecan-4 (SDC4) was the most down-regulated gene (fold change $=-2.35$ ) in high-FE muscle. SDC4 is a gene 


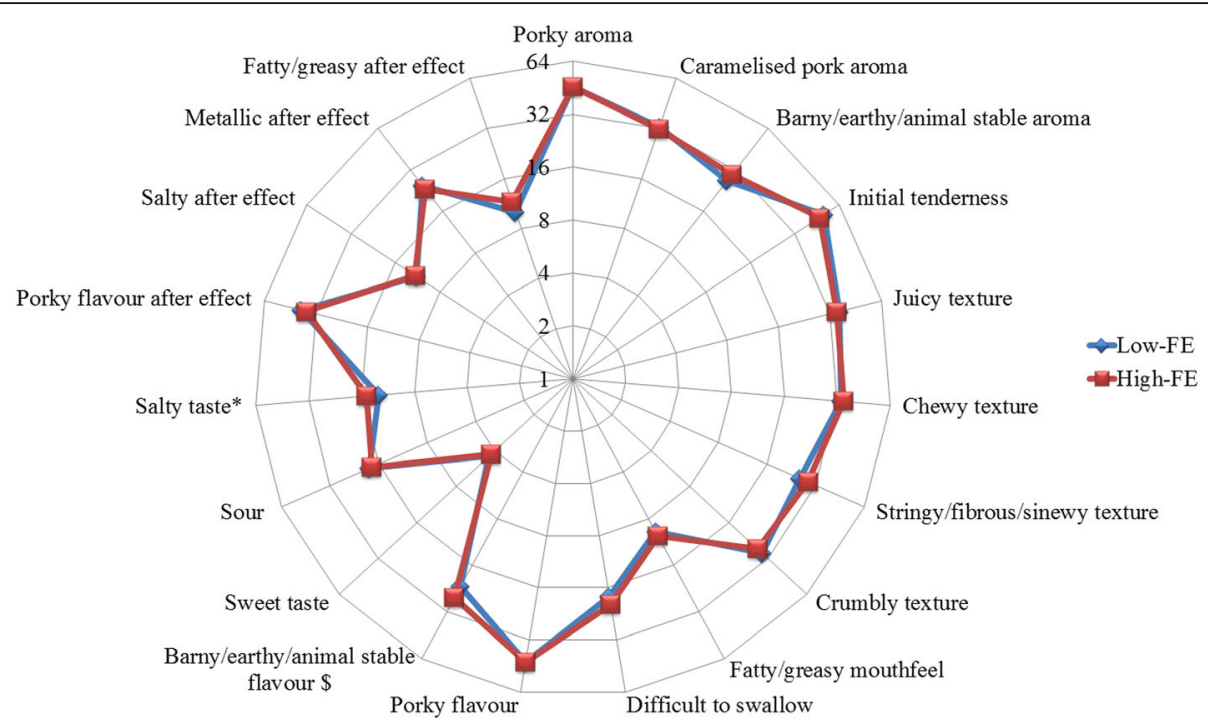

Fig. 3 Radar chart illustrating meat sensory attributes of Longissimus thoracis et lumborum muscle from FE-divergent pigs. Panellists scored meat from 0 (not detectable) to 100 (extremely detectable). ${ }^{\$} P<0.1,{ }^{*} P<0.05$

encoding plasma membrane proteoglycans and has been previously shown to have an impact on muscle cell proliferation and differentiation [41]. Knock down of SDC4 has been associated with increased myogenic regulatory transcription factor [42] and myogenin expressions, as well as increased muscle differentiation [43], which signify its importance to muscle growth. Integrating functional annotations of DE genes revealed a number of biological processes related to growth. 'Tissue development' and 'cardiovascular system development \& function' were significantly enriched categories

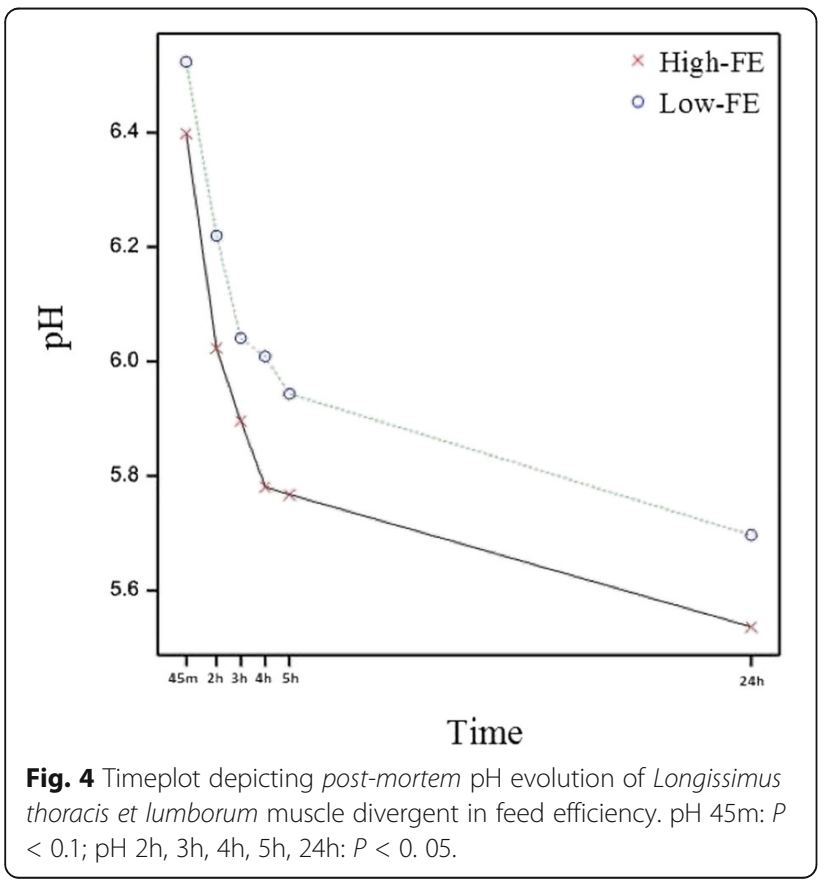

amongst the DE genes, with forkhead box O1 $($ FOXO1) being included (fold change $=-1.49)$ in both categories. FOXO1 belongs to the FOXO forkhead type family of transcription factors and it plays a role in modulation of skeletal muscle angiogenesis and function [44]. Mice over-expressing FOXO1 were found to weigh less and had a decreased skeletal muscle mass [45].

'Mobilisation and flux of $\mathrm{Ca}^{2+}$ ', contained within a 'vitamin and mineral metabolism' category, were significantly activated in high-FE pigs ( $\mathrm{z}$-score $=2.9$ and 2.4 , respectively). Calcium plays a key role in function and plasticity of skeletal muscle. It regulates skeletal muscle formation [46, 47], homeostasis and regeneration as well as being a crucial component triggering muscle contraction that enables movement [47] and furthermore plays an important role post-mortem in tenderness development [48]. Moreover 'synthesis of alpha-amino acids' and 'catabolism of L-tryptophan', enclosed within an 'amino acid metabolism' category, as well as 'production of protein', contained within 'protein metabolism' category, were significantly enriched amongst DE genes. L-tryptophan is an alpha-amino acid that positively influences production of protein in skeletal muscle and growth performance [49]. L-tryptophan is also a precursor of a broad range of compounds regulating appetite therefore playing a role in FE [49]. Although muscle and adipose depth did not significantly differ between the FE groups, down-regulation of SDC4 \& FOXO1, altered amino acid metabolism and increased mobilisation \& flux of $\mathrm{Ca} 2+$ may impact, at least to some extent, growth in FE-divergent pigs. 

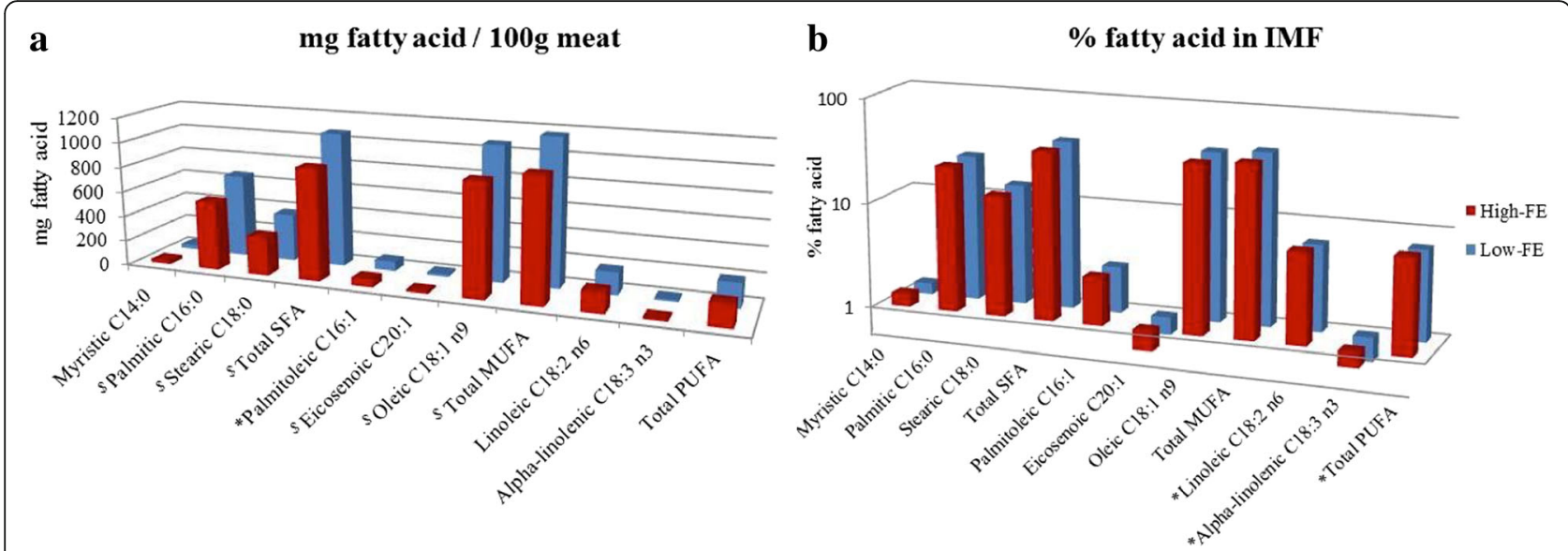

Fig. 5 Bar chart illustration of fatty acids composition of pigs divergent in feed efficiency (FE). Bar chart (a) displays fatty acid composition in Longissimus thoracis et lumborum muscle and (b) shows percentage of fatty acid in intramuscular fat (IMF). SFA: saturated fatty acids, MUFA: monounsaturated fatty acids, PUFA: polyunsaturated fatty acids. ${ }^{\$} P<0.1,{ }^{*} P<0.05$

\section{$\mathrm{FE}$, connective tissue and tenderness}

Collagen type XI alpha 1 chain (COL11A1) and collagen type VI alpha 5 chain (COL6A5) were up-regulated (fold change $=1.52$ and 1.77 , respectively) in high-FE pigs. Over-expression of COL11A1 has been associated with decreased tenderness in heifers [50]. Also, a single-nucleotide polymorphism in this gene was identified to have a consistent association with meat tenderness across three cattle breeds [51]. This study highlights that its relevance to tenderness development is also conserved in porcine muscle. Ontology analysis highlighted several functions also related to connective tissue, for example 'apoptosis of fibroblast cell lines', enclosed within 'cell death and survival' category, was significantly inhibited in high-FE pigs ( $\mathrm{z}$-score $=-2.27$ ). All of the DE genes represented in this category were also enriched in 'cell death of connective tissue' ( $\mathrm{z}$-score $=-1.18$ ), which also falls under the broader 'cell death and survival' function. Apoptosis and the stress response have been implicated as important factors in tenderisation. Specifically, apoptosis and cell death is considered the first step in promotion of tenderisation and factors which downregulate apoptosis, such as heat shock protein expression can inhibit tenderisation [52-54]. In the present study, the more efficient pigs produced muscle that tenderised more slowly, with significantly tougher pork on day $1 \mathrm{pm}$ compared with less efficient counterparts. Even by day $7 \mathrm{pm}$, while the differences in shear force were small, a tendency towards increased toughness remained. In this scenario the modulation of apoptosis as observed through our gene expression studies may have contributed to this differential ageing associated with FE and should be a matter of consideration in further driving improvements in FE. Fibroblasts are the key players in the synthesis of extracellular matrix components such as collagen [55, 56]. Amongst down-regulated transcripts in muscle of high-FE pigs were nuclear factor of activated T-cells 1 (NFATC1), nuclear factor of activated T-cells 2 (NFATC2) and MYC (fold change $=-1.30,-1.25$ and -1.57 , respectively) that have previously been shown to induce apoptosis in fibroblasts $[39,57,58]$. Correlation analysis between DE genes and product quality traits showed a negative correlation between NFATC2 and cook loss on day $1 \mathrm{pm}$, whilst NTAFC1 had a tendency towards being negatively correlated with cook loss on day $1 \mathrm{pm}$. Consistent with a role for apoptosis in tenderness development [54], NFATC1 was also positively correlated with a measure of toughness, WBSF on day $7 \mathrm{pm}$ (higher values indicate decreased tenderness). PC analysis revealed a positive correlation between NFATC2 and stringiness (Fig. 6b). Moreover, WBSF was correlated with $\mathrm{N}$-acylethanolamine acid amidase (NAAA), a pro-inflammatory gene closely related to acid ceramidase [59], which has been shown to influence locomotory behaviour [60]. This may explain the positive correlation between NAAA and texture, known to be associated with load-bearing and functionality of specific muscles, with more load-bearing and active muscle producing tougher meat [61]. PC analysis further highlighted several other genes in relation to meat quality. Specifically, rap guanine nucleotide exchange factor 3 (RAPGEF3; involved in angiogenesis [62]) and NFATC1 co-located with texture traits, including WBSF, stringiness and difficulty in swallowing, whilst crumbliness was situated on the opposite end of the biplot (Fig. 6b). These observations were also noted in the correlation analysis (Table 6). With a complex array of correlated traits, and numerous differentially expressed genes in consideration, this study illustrates the utility of a holistic multivariate approach such as PCA in identifying novel candidates for association with traits of interest. 
Table 5 Correlations between product quality traits and selected differentially expressed genes, out of the 272 , in pigs divergent for feed efficiency.

\begin{tabular}{|c|c|c|c|c|c|c|c|c|c|c|c|c|c|c|}
\hline Gene & $\mathrm{pH} 45 \mathrm{~m}$ & $\mathrm{pH} 24 \mathrm{~h}$ & $\mathrm{DL}$ & WBSF D1 & WBSF D7 & CL D1 & CL D7 & Fat depth & Muscle depth & Lean & IMF & SFA & MUFA & PUFA \\
\hline \multirow[t]{2}{*}{ CCR2 } & 0 & -0.51 & 0.44 & 0.01 & 0.16 & 0.2 & 0.06 & 0.01 & -0.08 & 0.01 & -0.38 & -0.26 & -0.22 & -0.37 \\
\hline & 0.99 & 0.04 & 0.09 & 0.98 & 0.56 & 0.45 & 0.83 & 0.96 & 0.77 & 0.97 & 0.15 & 0.34 & 0.41 & 0.16 \\
\hline \multirow[t]{2}{*}{ COL11A1 } & 0.44 & -0.45 & -0.13 & 0.04 & -0.46 & 0.25 & 0.24 & -0.32 & -0.42 & 0.14 & -0.03 & 0 & -0.02 & 0.14 \\
\hline & 0.09 & 0.08 & 0.64 & 0.88 & 0.07 & 0.36 & 0.38 & 0.23 & 0.11 & 0.6 & 0.92 & 1 & 0.93 & 0.59 \\
\hline \multirow[t]{2}{*}{ COL6A5 } & 0.34 & -0.46 & 0.27 & 0.24 & 0.31 & 0.42 & 0.21 & -0.11 & 0.12 & 0.29 & -0.22 & -0.41 & -0.43 & -0.18 \\
\hline & 0.2 & 0.07 & 0.31 & 0.37 & 0.24 & 0.11 & 0.44 & 0.69 & 0.67 & 0.28 & 0.42 & 0.12 & 0.1 & 0.51 \\
\hline \multirow[t]{2}{*}{ CXCL10 } & 0.31 & -0.25 & 0.22 & -0.07 & -0.13 & 0.37 & -0.29 & -0.34 & 0.04 & 0.36 & -0.63 & -0.61 & -0.65 & -0.46 \\
\hline & 0.24 & 0.35 & 0.41 & 0.8 & 0.64 & 0.16 & 0.27 & 0.19 & 0.88 & 0.16 & 0.01 & 0.01 & 0.01 & 0.07 \\
\hline \multirow[t]{2}{*}{$C Y B B$} & 0.28 & -0.4 & 0.3 & -0.04 & 0.21 & 0.11 & -0.04 & -0.44 & 0.06 & 0.5 & -0.59 & -0.53 & -0.54 & -0.36 \\
\hline & 0.29 & 0.13 & 0.26 & 0.89 & 0.44 & 0.7 & 0.89 & 0.09 & 0.82 & 0.04 & 0.02 & 0.04 & 0.03 & 0.16 \\
\hline \multirow[t]{2}{*}{ FOXO1 } & -0.43 & 0.52 & -0.2 & 0.02 & 0.08 & -0.63 & -0.35 & 0.54 & 0.16 & -0.53 & 0.26 & 0.5 & 0.62 & 0.09 \\
\hline & 0.1 & 0.04 & 0.46 & 0.93 & 0.77 & 0.01 & 0.19 & 0.03 & 0.55 & 0.04 & 0.32 & 0.04 & 0.01 & 0.74 \\
\hline \multirow[t]{2}{*}{ GM2A } & 0.39 & -0.57 & 0.28 & -0.14 & -0.09 & 0.4 & 0.33 & -0.41 & -0.28 & 0.39 & -0.33 & -0.37 & -0.43 & -0.1 \\
\hline & 0.14 & 0.02 & 0.29 & 0.61 & 0.73 & 0.12 & 0.22 & 0.12 & 0.29 & 0.14 & 0.22 & 0.16 & 0.1 & 0.71 \\
\hline \multirow[t]{2}{*}{ HK3 } & 0.09 & -0.35 & 0.08 & -0.23 & -0.05 & 0.35 & -0.31 & -0.7 & 0.07 & 0.68 & -0.54 & -0.63 & -0.74 & -0.37 \\
\hline & 0.75 & 0.19 & 0.76 & 0.4 & 0.85 & 0.19 & 0.24 & $<0.01$ & 0.81 & $<0.01$ & 0.03 & 0.01 & $<0.01$ & 0.16 \\
\hline \multirow[t]{2}{*}{ LPCAT2 } & 0.35 & -0.34 & -0.11 & -0.01 & -0.25 & 0.48 & 0.29 & -0.35 & -0.16 & 0.27 & -0.22 & -0.20 & -0.27 & 0.09 \\
\hline & 0.18 & 0.20 & 0.68 & 0.98 & 0.35 & 0.06 & 0.27 & 0.18 & 0.55 & 0.32 & 0.41 & 0.46 & 0.31 & 0.73 \\
\hline \multirow[t]{2}{*}{ ETV1 } & 0.31 & -0.37 & 0.09 & 0.30 & 0.11 & 0.38 & 0.23 & -0.33 & -0.04 & 0.33 & -0.36 & -0.34 & -0.38 & -0.13 \\
\hline & 0.25 & 0.16 & 0.75 & 0.26 & 0.68 & 0.14 & 0.40 & 0.21 & 0.90 & 0.22 & 0.16 & 0.19 & 0.15 & 0.63 \\
\hline \multirow[t]{2}{*}{ NAAA } & -0.11 & -0.33 & 0.47 & -0.05 & 0.36 & 0.05 & -0.09 & -0.14 & 0.03 & 0.18 & -0.44 & -0.38 & -0.38 & -0.33 \\
\hline & 0.69 & 0.22 & 0.07 & 0.86 & 0.18 & 0.86 & 0.74 & 0.61 & 0.93 & 0.51 & 0.08 & 0.15 & 0.14 & 0.21 \\
\hline \multirow[t]{2}{*}{ RAPGEF3 } & -0.33 & 0.24 & -0.08 & 0.18 & 0.47 & -0.49 & -0.06 & 0.40 & 0.12 & -0.40 & 0.42 & 0.57 & 0.60 & 0.15 \\
\hline & 0.21 & 0.36 & 0.76 & 0.50 & 0.07 & 0.05 & 0.83 & 0.13 & 0.66 & 0.12 & 0.10 & 0.02 & 0.01 & 0.59 \\
\hline \multirow[t]{2}{*}{ ITGB2 } & 0.36 & -0.52 & 0.35 & -0.09 & 0.1 & 0.41 & 0.06 & -0.49 & -0.14 & 0.53 & -0.5 & -0.54 & -0.6 & -0.37 \\
\hline & 0.17 & 0.04 & 0.18 & 0.75 & 0.71 & 0.12 & 0.84 & 0.04 & 0.6 & 0.04 & 0.04 & 0.03 & 0.01 & 0.15 \\
\hline \multirow[t]{2}{*}{$L I P C$} & -0.04 & -0.08 & 0.24 & 0 & 0.27 & 0.15 & -0.05 & -0.06 & 0.41 & 0.17 & -0.24 & -0.36 & -0.44 & -0.28 \\
\hline & 0.87 & 0.78 & 0.38 & 0.99 & 0.32 & 0.59 & 0.85 & 0.82 & 0.12 & 0.52 & 0.37 & 0.16 & 0.09 & 0.29 \\
\hline \multirow[t]{2}{*}{ MYC } & 0.01 & 0.46 & -0.21 & -0.23 & 0.09 & -0.72 & -0.14 & 0.1 & 0.25 & -0.03 & 0.24 & 0.28 & 0.26 & 0.2 \\
\hline & 0.97 & 0.07 & 0.44 & 0.39 & 0.73 & $<0.01$ & 0.6 & 0.7 & 0.36 & 0.92 & 0.38 & 0.29 & 0.32 & 0.47 \\
\hline \multirow[t]{2}{*}{ NEU3 } & -0.24 & -0.24 & 0.54 & 0.23 & 0.62 & 0.12 & 0.06 & 0.14 & -0.11 & -0.14 & -0.06 & -0.07 & -0.06 & -0.06 \\
\hline & 0.38 & 0.38 & 0.03 & 0.39 & 0.01 & 0.65 & 0.84 & 0.62 & 0.69 & 0.61 & 0.84 & 0.8 & 0.81 & 0.82 \\
\hline \multirow[t]{2}{*}{ NFATC1 } & -0.23 & 0.12 & 0.21 & 0.28 & 0.7 & -0.49 & -0.32 & 0.34 & 0.36 & -0.24 & 0.14 & 0.21 & 0.25 & -0.13 \\
\hline & 0.39 & 0.65 & 0.42 & 0.29 & $<0.01$ & 0.06 & 0.23 & 0.19 & 0.17 & 0.36 & 0.61 & 0.43 & 0.36 & 0.63 \\
\hline \multirow[t]{2}{*}{ NFATC2 } & -0.29 & 0.38 & 0.07 & -0.12 & 0.35 & -0.81 & -0.27 & 0.57 & 0.35 & -0.44 & 0.28 & 0.38 & 0.46 & -0.08 \\
\hline & 0.28 & 0.15 & 0.8 & 0.66 & 0.18 & $<0.01$ & 0.31 & 0.02 & 0.18 & 0.09 & 0.3 & 0.15 & 0.07 & 0.76 \\
\hline \multirow[t]{2}{*}{ PDK4 } & -0.41 & 0.46 & -0.59 & 0.14 & -0.1 & -0.27 & -0.25 & 0.18 & 0.08 & -0.25 & 0.33 & 0.48 & 0.51 & 0.26 \\
\hline & 0.11 & 0.08 & 0.02 & 0.62 & 0.72 & 0.32 & 0.35 & 0.5 & 0.77 & 0.35 & 0.21 & 0.06 & 0.05 & 0.32 \\
\hline \multirow[t]{2}{*}{ PIK3C2B } & -0.02 & -0.22 & 0.51 & -0.09 & 0.16 & 0.13 & 0.27 & 0.22 & -0.5 & -0.4 & 0.06 & 0.19 & 0.21 & 0.18 \\
\hline & 0.95 & 0.42 & 0.04 & 0.73 & 0.55 & 0.63 & 0.31 & 0.41 & 0.05 & 0.13 & 0.84 & 0.47 & 0.44 & 0.5 \\
\hline PLIN1 & 0.18 & 0.3 & -0.49 & -0.26 & -0.32 & -0.22 & 0.34 & -0.02 & -0.17 & -0.11 & 0.51 & 0.61 & 0.61 & 0.59 \\
\hline & 0.51 & 0.27 & 0.05 & 0.33 & 0.23 & 0.41 & 0.2 & 0.95 & 0.52 & 0.69 & 0.04 & 0.01 & 0.01 & 0.02 \\
\hline PON3 & 0.32 & -0.3 & -0.04 & 0.25 & -0.14 & 0.56 & 0.62 & -0.13 & -0.31 & 0.07 & -0.01 & -0.06 & -0.05 & 0.28 \\
\hline
\end{tabular}


Table 5 Correlations between product quality traits and selected differentially expressed genes, out of the 272, in pigs divergent for feed efficiency. (Continued)

\begin{tabular}{|c|c|c|c|c|c|c|c|c|c|c|c|c|c|c|}
\hline Gene & $\mathrm{pH} 45 \mathrm{~m}$ & $\mathrm{pH} 24 \mathrm{~h}$ & $\mathrm{DL}$ & WBSF D1 & WBSF D7 & CL D1 & CL D7 & Fat depth & Muscle depth & Lean & IMF & SFA & MUFA & PUFA \\
\hline & 0.23 & 0.26 & 0.88 & 0.34 & 0.62 & 0.02 & 0.01 & 0.63 & 0.24 & 0.8 & 0.98 & 0.82 & 0.86 & 0.3 \\
\hline \multirow[t]{2}{*}{ SDC4 } & -0.32 & 0.54 & -0.19 & -0.04 & 0.21 & -0.5 & -0.58 & 0.14 & 0.41 & 0 & -0.05 & 0.02 & 0.07 & -0.22 \\
\hline & 0.23 & 0.03 & 0.49 & 0.87 & 0.44 & 0.05 & 0.02 & 0.59 & 0.11 & 1 & 0.85 & 0.93 & 0.8 & 0.41 \\
\hline \multirow[t]{2}{*}{ SLCIA2 } & 0.09 & -0.53 & 0.29 & 0.35 & 0.2 & 0.51 & -0.24 & -0.52 & -0.23 & 0.44 & -0.61 & -0.47 & -0.53 & -0.29 \\
\hline & 0.76 & 0.04 & 0.29 & 0.21 & 0.48 & 0.05 & 0.38 & 0.05 & 0.41 & 0.1 & 0.02 & 0.08 & 0.04 & 0.29 \\
\hline \multirow[t]{2}{*}{ TREH } & 0.23 & -0.27 & 0.45 & -0.28 & 0.15 & 0.05 & 0.33 & -0.06 & -0.23 & 0.01 & -0.16 & -0.18 & -0.19 & 0.02 \\
\hline & 0.41 & 0.33 & 0.09 & 0.31 & 0.59 & 0.85 & 0.23 & 0.83 & 0.42 & 0.97 & 0.58 & 0.52 & 0.49 & 0.95 \\
\hline
\end{tabular}

Correlation coefficient is presented in the upper row and a $P$-value is shown in the bottom row. Significant correlations are highlighted in bold. $D L$ drip loss (\%), WBSF D1 Warner Bratzler shear force day 1 pm (N), WBSF D7 Warner Bratzler shear force day 7 pm (N), CL D1 cook loss day 1 pm (\%), CL D7 cook loss day 7 pm (\%), Fat depth (mm), Muscle depth (mm), Lean (\%), IMF intramuscular fat content (\%), SFA saturated fatty acid (mg), MUFA monounsaturated fatty acid (mg), PUFA polyunsaturated fatty acid (mg)

Besides connective tissue, tenderness of meat has been shown to be influenced by greater calpastatin activity through decreased $p m$ protein degradation [17], In the present study, calpastatin (CAST) had a tendency towards being down-regulated $(P<0.1$, fold change $=$ -1.17) in high-FE pigs which is not expected given our observation that tenderness was impaired in high-FE pigs, furthermore tenderness development was slower in this group. This negative correlation between $C A S T$ and tenderness was also demonstrated in the PCA biplot with WBSF (day 1 and $7 \mathrm{pm}$ ) and CAST being located on opposite ends of PC-2. While calpastatin has been shown to be negatively associated with tenderness, most of this work has been done in beef [63-66] and its relationship with pork quality may be more important in relation to water-holding capacity [38]. Nevertheless, the altered tenderness of FE-divergent meat could be partially impacted by shifts in collagen turnover resulting from decreased degradation of fibroblasts.

\section{Lipid metabolism changes associated with FE}

Muscle depth and leanness did not differ between the FE groups, which contrast previous reports [13, 14, 16, 17]. However, here and in prior studies, selection for high-FE was associated with reduced IMF [14, 16, 17]. Over the past decades, consumers have become more conscious with regards to wholesome eating and seeking healthier options [6]. Meat from high-FE pigs exhibited tendencies towards decreased levels of SFA and MUFA, which are known to be the major constituents of triacylglycerol $[67,68]$ and are associated with increased risk of cardiovascular disease [69, 70]. Higher proportions of PUFA, whilst lower levels of SFA and MUFA, has been previously associated with reduced IMF content $[68,71,72]$. Indeed, the IMF of meat from high-FE pigs was 12 percent richer in PUFA compared to IMF from low-FE group. PUFA has been shown to reduce low-density lipoprotein cholesterol levels and exhibit protective properties against cardiovascular disease [15], therefore suggesting that meat from high-FE pigs may have a healthier fatty acid profile. Underpinning these changes, functions and pathways important in metabolism of lipids were also affected by $\mathrm{FE}$, as evident from the ontology analysis, specifically 'concentration of lipids, cholesterol \& triacylglycerol' and 'fatty acid metabolism, enclosed within a broader 'lipid metabolism' category. Correlation analysis between DE genes, enriched in 'lipid metabolism' category, and product quality traits revealed a number of significant correlations. FOXO1 (fold change $=-1.49$ ), which was previously shown to play a role in adipogenesis in cattle [73], was positively correlated with fat depth, SFA and MUFA, and also negatively correlated with lean percentage. Cytochrome B-245 beta chain $(C Y B B$; fold change $=1.56)$ was positively correlated with percent lean and negatively correlated with IMF, SFA and MUFA. A previous study conducting expression profiling of porcine adipose tissue suggested CYBB to play a role in fat metabolism and adipogenic differentiation [74]. Correlation analysis has also revealed Perilipin 1 (PLIN 1; fold change $=-1.42$ ) to be positively correlated with IMF, SFA, MUFA and PUFA and this is in keeping with a previous study reporting its higher abundance being associated with increased IMF in porcine muscle [75]. Moreover, C-X-C motif chemokine ligand $10(C X C L 10$, fold change $=2.24)$, which was previously associated to marbling in cattle [76], was negatively correlated with IMF, SFA and MUFA.

Furthermore, the second most significant network (network \#2), identified through the functional annotation analysis, contained several features related to 'lipid metabolism,' 'molecular transport' and 'protein synthesis'. Paraoxonase 3 (PON3) and triacylglycerol lipase (LIPC) were the most up-regulated genes in this network (fold change $=4.40$ and 3.51, respectively). PON3, an enzyme belonging to the PON family, associates with high density lipoproteins (HDL) [77], which are lipid particles that function to export excess cholesterol from muscle and adipose tissue to the liver [78]. PON3 knockout mice have previously been shown to exhibit increased body weight [79], which points towards a 
Table 6 Correlations between product sensory traits and selected differentially expressed genes, out of the 272, in pigs divergent for feed efficiency

\begin{tabular}{|c|c|c|c|c|c|c|c|c|c|c|c|c|c|c|c|c|c|c|c|}
\hline Gene/trait $^{a}$ & 1 & 2 & 3 & 4 & 5 & 6 & 7 & 8 & 9 & 10 & 11 & 12 & 13 & 14 & 15 & 16 & 17 & 18 & 19 \\
\hline \multirow[t]{2}{*}{$\overline{C C R 2}$} & 0.26 & 09 & -0.30 & 13 & 18 & 0.04 & 0.13 & 0.23 & -0.25 & 0.09 & 0.11 & 0.17 & -0.37 & -0.31 & 0.00 & -0.24 & 0.23 & -0.10 & -0.14 \\
\hline & 0.32 & 73 & 0.25 & 0.64 & 0.51 & 0.89 & 0.63 & 40 & 0.34 & 0.75 & 0.70 & 0.53 & 0.16 & 0.24 & 1.00 & 0.36 & 0.40 & 0.72 & 0.59 \\
\hline \multirow[t]{2}{*}{ COL11A } & 016 & 33 & 0.07 & -0.02 & -0.25 & -0.05 & -0.24 & 0.52 & 0.35 & -0.16 & 0.01 & -0.14 & 0.48 & 0.25 & 0.00 & 0.18 & -0.16 & 0.42 & 0.76 \\
\hline & 0.56 & 0.21 & 0.81 & 0.95 & 0.34 & 0.86 & 0.36 & 0.04 & 0.18 & 0.55 & 0.97 & 0.62 & 0.06 & 0.34 & 0.99 & 0.51 & 0.54 & 0.10 & $<0.01$ \\
\hline \multirow[t]{2}{*}{ COL6A5 } & 0.01 & 0.08 & 0.11 & -0.12 & 0.20 & 0.10 & -0.07 & -0.07 & 0.15 & 0.19 & 0.10 & 0.27 & -0.14 & 0.04 & 0.28 & -0.13 & -0.16 & 0.08 & -0.11 \\
\hline & 0.90 & 10 & 0.68 & 0.66 & 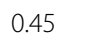 & 0.70 & 0.79 & 0.00 & 0.59 & 0.47 & 0.71 & 0.31 & .02 & 0.89 & 0.30 & 0.63 & 0.54 & 78 & 0.70 \\
\hline \multirow[t]{2}{*}{ CXCL10 } & 0.06 & 0.34 & 0.08 & -0.11 & -0.29 & 0.15 & -0.02 & 0.29 & 0.50 & 0.09 & -0.05 & -0.03 & 0.23 & 0.10 & -0.17 & 0.05 & -0.56 & 0.40 & 0.39 \\
\hline & 0.83 & 0.19 & 0.78 & 0.68 & 0.27 & 0.57 & 0.95 & 0.27 & 0.04 & 0.74 & 0.85 & 0.92 & 0.40 & 0.71 & 0.53 & 0.86 & 0.02 & 0.13 & 0.13 \\
\hline \multirow[t]{2}{*}{$C Y B B$} & -0.39 & -0.16 & 0.15 & -0.24 & -0.21 & 0.04 & -0.11 & -0.28 & 0.10 & 0.02 & 0.36 & 0.00 & -0.40 & -0.15 & -0.26 & -0.59 & 0.14 & -0.45 & -0.14 \\
\hline & 14 & 56 & 0.59 & 0.36 & 0.44 & 0.88 & 0.69 & 9 & 0.72 & 0.95 & 0.17 & 1.00 & 0.13 & 0.59 & 0.33 & 0.02 & 0.61 & 0.08 & 0.59 \\
\hline \multirow[t]{2}{*}{ FOXO1 } & -0.23 & -0.33 & 0.01 & -0.11 & -0.19 & 0.29 & 0.32 & -0.36 & -0.55 & 0.27 & -0.18 & 0.13 & -0.41 & -0.18 & 0.18 & 0.05 & 0.36 & -0.05 & -0.38 \\
\hline & 0.39 & 0.22 & 0.97 & 0.70 & 0.49 & 0.28 & 0.22 & 0.16 & 0.03 & 0.31 & 0.51 & 0.63 & 0.12 & 0.51 & 0.51 & 0.85 & 0.16 & 0.86 & 0.15 \\
\hline \multirow[t]{2}{*}{ GM2A } & 21 & 111 & -0.05 & -0.06 & 0.02 & -0.11 & -0.17 & -0.02 & 0.14 & -0.09 & 0.51 & 0.16 & -0.11 & -0.15 & -0.14 & -0.43 & 0.15 & 14 & 0.15 \\
\hline & 0.43 & 0.69 & 0.85 & 0.81 & 0.93 & 0.69 & 0.53 & 0.93 & 0.62 & 0.75 & 0.04 & 0.56 & 0.67 & 0.57 & 0.59 & 0.09 & 0.57 & 0.60 & 0.57 \\
\hline \multirow[t]{2}{*}{ HK3 } & -0.11 & 0.06 & -0.17 & 0.03 & -0.06 & -0.21 & -0.16 & 0.05 & 0.48 & -0.31 & 0.30 & -0.12 & -0.09 & 0.05 & -0.37 & -0.34 & -0.14 & -0.11 & 0.05 \\
\hline & 0.70 & 0.83 & 0.53 & 0.92 & 0.82 & 0.42 & 0.55 & 0.86 & 0.06 & 0.25 & 0.26 & 0.66 & 0.75 & 0.85 & 0.15 & 0.20 & 0.62 & 0.69 & 0.86 \\
\hline \multirow[t]{2}{*}{ LPCAT2 } & 0.31 & 0.52 & 0.07 & 0.09 & -0.07 & -0.17 & -0.18 & 0 & 028 & -0.34 & -0.17 & -0.30 & 0.33 & 021 & -0.09 & 0.02 & -0.35 & 0.30 & 0.60 \\
\hline & 24 & 04 & 0.79 & 0.74 & 0.80 & 0.53 & 0.50 & 0.24 & 0.29 & 0.19 & 0.53 & 0.25 & 0.22 & 0.43 & 0.75 & 0.94 & 0.18 & 0.26 & 0.01 \\
\hline \multirow[t]{2}{*}{ ETV1 } & 0.34 & 0.47 & 0.13 & -0.20 & -0.23 & 0.04 & -0.10 & 0.21 & 0.37 & -0.20 & -0.15 & -0.42 & 0.28 & 0.14 & -0.05 & -0.18 & -0.47 & 0.10 & 0.46 \\
\hline & $=$ & 0.07 & 0.63 & 0 & 0.39 & 0 & 0.70 & 0.44 & 0 & 0 & 0.59 & 0.1 & 0. & 0.62 & 0.85 & 0.51 & 0.06 & 1 & 8 \\
\hline \multirow[t]{2}{*}{ NAAA } & -0.50 & -0.35 & -0.02 & -0.10 & 0.01 & 0.02 & 0.11 & -0.51 & -0.11 & 0.04 & 0.34 & -0.01 & -0.65 & -0.26 & -0.13 & -0.59 & 0.26 & -0.43 & -0.35 \\
\hline & 0.04 & 0.18 & 0.94 & 0.70 & 0.98 & 0.93 & 0.68 & 0.04 & 0.68 & 0.89 & 0.20 & 0.97 & 0.01 & 0.33 & 0.63 & 0.02 & 0.32 & 0.10 & 0.18 \\
\hline \multirow[t]{2}{*}{ RAPGEF3 } & -0.13 & -0.20 & -0.26 & -0.43 & -0.11 & 0.47 & 0.76 & -0.65 & -0.61 & 0.46 & 0.01 & -0.12 & -0.31 & -0.38 & 0.34 & -0.01 & 0.31 & -0.15 & -0.50 \\
\hline & 0.63 & 0.46 & 0.33 & 0.09 & 0.67 & 0.07 & $<0.01$ & 0.01 & 0.01 & 0.07 & 0.96 & 0.66 & 0.24 & 0.15 & 0.20 & 0.98 & 0.24 & 0.58 & 0.04 \\
\hline \multirow[t]{2}{*}{ ITGB2 } & 26 & -0.09 & $-c$ & -0.33 & 2 & 0 & 0.10 & -0.15 & 0.19 & 0.22 & 0.63 & 0.23 & 2 & -0.24 & 6 & 3 & 0.00 & 4 & 5 \\
\hline & 0.32 & 0.73 & 0.57 & 0.21 & 0.66 & 0.58 & 0.70 & 0.57 & 0.47 & 0.41 & 0.01 & 0.39 & 0.66 & 0.37 & 0.54 & 0.09 & 0.99 & 0.62 & 0.87 \\
\hline \multirow[t]{2}{*}{ LIPC } & 1325 & 0.24 & 0 & 0.10 & 0 & -0.10 & -0.0 & 4 & 0 & -0.22 & -0.40 & -0.34 & 0 & 0 & 4 & 0.06 & -036 & 005 & 0.04 \\
\hline & 0.64 & 0.36 & 0.63 & 0.72 & 0.69 & 0.71 & 0.95 & 0.90 & 0.36 & 0.41 & 0.13 & 0.20 & 1.00 & 0.75 & 0.61 & 0.82 & 0.17 & 0.85 & 0.89 \\
\hline \multirow[t]{2}{*}{ MYC } & 0.19 & -0.48 & 0.20 & -0.24 & -0.42 & 0.18 & 0.09 & -0.31 & -0.21 & 0.10 & 0.21 & -0.10 & -0.26 & -0.29 & -0.02 & -0.28 & 0.36 & -0.43 & -0.29 \\
\hline & 0.49 & 0.06 & 0.45 & 0 & 0.11 & 0. & 0 & 0.24 & 0 & 0.72 & 0.43 & 0.72 & 0. & 0 & 0 & 0 & 0.18 & 0.10 & 0 \\
\hline \multirow[t]{2}{*}{ NEU3 } & -0.35 & -0.34 & -0.15 & 0.06 & 0.46 & 0.04 & 0.29 & -0.59 & -0.23 & 0.25 & 0.20 & -0.01 & -0.56 & -0.16 & 0.24 & -0.25 & 0.18 & -0.40 & -0.59 \\
\hline & 0.19 & 0.20 & 0 & c & 0.07 & 0 & 0 & 0.02 & 0 & 0.35 & 0.46 & 08 & 3 & 0 & 0 & 0 & 0.51 & 0 & 2 \\
\hline \multirow[t]{2}{*}{ NFATC1 } & -0.29 & -0.26 & -0.03 & -0.31 & 0.02 & 0.45 & 0.55 & -0.68 & -0.36 & 0.52 & -0.17 & -0.07 & -0.52 & -0.23 & 0.37 & 0.06 & 0.17 & -0.23 & -0.68 \\
\hline & .27 & 32 & 0.90 & 0.25 & 0.95 & 0.08 & 0.03 & $<0.01$ & 0.16 & 0.04 & 0.53 & 0.79 & 0.04 & 0.40 & 0.16 & 0.82 & 0.52 & 0.39 & $<0.01$ \\
\hline NFATC2 & -0.29 & -0.25 & -0.17 & -0.26 & 0.00 & 0.27 & 0.37 & -0.46 & -0.66 & 0.43 & -0.06 & 0.16 & -0.46 & -0.49 & 0.21 & 0.04 & 0.52 & -0.41 & -0.71 \\
\hline & 0.27 & 0.35 & 0.53 & 0.34 & 0.99 & 0.32 & 0.15 & 0.07 & 0.01 & 0.10 & 0.81 & 0.56 & 0.07 & 0.06 & 0.42 & 0.90 & 0.04 & 0.12 & $<0.01$ \\
\hline 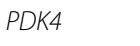 & 11 & -0.12 & 4 & -0.16 & -0.45 & $0.2^{2}$ & 0.36 & .17 & -0.19 & 0.01 & -0.14 & -0.13 & -0.03 & 0.13 & 0. & 0 & .00 & 0.34 & ( \\
\hline & 0.69 & 0.66 & 0.88 & 0.55 & 0.09 & 0.30 & 0.17 & 0.53 & 0.49 & 0.97 & 0.59 & 0.63 & 0.91 & 0.64 & 0.65 & 0.91 & 0.99 & 0.19 & 0.79 \\
\hline 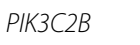 & -0.14 & 0.11 & -0.48 & 0.36 & 0.75 & -0.26 & 0.14 & -0.19 & -0.43 & 0.13 & 0.05 & -0.06 & -0.19 & -0.31 & 0.18 & 0.09 & 0.26 & -0.41 & -0.32 \\
\hline & 0.62 & 0.68 & 0.06 & 0.18 & $<0.01$ & 0.33 & 0.61 & 0.49 & 0.10 & 0.64 & 0.85 & 0.83 & 0.49 & 0.25 & 0.50 & 0.74 & 0.32 & 0.12 & 0.22 \\
\hline PLIN1 & .12 & -0 & 0 & 0 & 0.17 & 8 & -0.05 & 18 & 9 & -0.04 & 0.09 & 4 & 1 & -0.01 & -0.09 & 12 & 4 & -0.27 & -0.13 \\
\hline & 0.66 & 0.56 & 0.94 & 0.53 & 0.53 & 0.50 & 0.85 & 0.51 & 0.06 & 0.88 & 0.75 & 0.59 & 0.98 & 0.96 & 0.75 & 0.66 & 0.03 & 0.31 & 0.64 \\
\hline PON3 & 0.13 & 0.17 & 0.42 & 0.16 & 0.09 & -0.14 & -0.27 & 0.18 & 0.12 & -0.13 & -0.04 & -0.01 & 0.24 & 0.39 & 0.03 & -0.04 & -0.21 & 0.19 & 0.45 \\
\hline
\end{tabular}


Table 6 Correlations between product sensory traits and selected differentially expressed genes, out of the 272, in pigs divergent for feed efficiency (Continued)

\begin{tabular}{llllllllllllllllllll}
\hline Gene/trait $^{\mathrm{a}}$ & 1 & 2 & 3 & 4 & 5 & 6 & 7 & 8 & 9 & 10 & 11 & 12 & 13 & 14 & 15 & 16 & 17 & 18 & 19 \\
\hline \multirow{3}{*}{ SDC4 } & 0.64 & 0.52 & 0.11 & 0.56 & 0.73 & 0.61 & 0.31 & 0.51 & 0.65 & 0.62 & 0.89 & 0.97 & 0.37 & 0.13 & 0.91 & 0.88 & 0.42 & 0.49 & 0.08 \\
& -0.24 & -0.45 & 0.10 & -0.37 & -0.48 & 0.41 & 0.34 & -0.39 & -0.16 & 0.34 & 0.17 & 0.19 & -0.36 & -0.19 & -0.04 & -0.24 & 0.11 & -0.13 & -0.47 \\
& 0.36 & 0.08 & 0.70 & 0.16 & 0.06 & 0.11 & 0.20 & 0.13 & 0.56 & 0.19 & 0.53 & 0.49 & 0.16 & 0.49 & 0.87 & 0.38 & 0.68 & 0.63 & 0.07 \\
SLC1A2 & -0.18 & -0.12 & -0.05 & -0.14 & -0.21 & 0.20 & 0.12 & -0.20 & 0.44 & 0.00 & 0.27 & -0.14 & -0.25 & 0.13 & 0.01 & -0.43 & -0.33 & 0.17 & 0.16 \\
& 0.52 & 0.67 & 0.87 & 0.61 & 0.45 & 0.47 & 0.67 & 0.48 & 0.10 & 0.99 & 0.33 & 0.63 & 0.37 & 0.64 & 0.97 & 0.11 & 0.24 & 0.54 & 0.56 \\
TREH & -0.29 & -0.01 & -0.04 & -0.04 & 0.10 & -0.10 & 0.08 & -0.20 & -0.21 & 0.14 & 0.33 & -0.12 & -0.20 & -0.30 & -0.04 & -0.37 & 0.17 & -0.46 & -0.12 \\
& 0.30 & 0.97 & 0.87 & 0.87 & 0.72 & 0.73 & 0.77 & 0.48 & 0.46 & 0.61 & 0.24 & 0.68 & 0.47 & 0.27 & 0.88 & 0.18 & 0.55 & 0.09 & 0.66
\end{tabular}

Correlation coefficient is presented in the upper row and a $P$-value is shown in the bottom row. Significant correlations are highlighted in bold. ${ }^{\mathrm{a}} 1$ : porky aroma, 2 : caramelised aroma, 3: barny aroma, 4: initial tenderness, 5: juicy, 6: chewy, 7: stringy, 8: crumbly, 9: fatty mouthfeel, 10: difficult to swallow, 11: salty, 12: sweet, 13: porky flavour, 14: barny flavour, 15: sour, 16: porky after effect, 17: salty after effect, 18: metallic after effect, 19: fatty after effect.

PON3 role in promoting a leaner muscle growth. The enzyme LIP catalyses hydrolysis of phospholipids and triacylglycerols [80]. Over-expression of LIPC in high-FE muscle suggests enhanced lipid degradation in this group of pigs and potentially underlies a more efficient fat metabolism in these animals.

\section{Conclusions}

Gene expression profiling of muscle from FE-divergent pigs provided mechanistic insights on the biological events prevailing differences in FE, which impact product quality. Small but significant changes in the quality of meat, in relation to texture and waterholding capacity, from high-FE pigs, were observed. High-FE muscle was characterised by reduced intramuscular fat content and improved nutritional profile in terms of fatty acid composition. Ontology analysis revealed enhanced activity of adaptive immunity and phagocytes in high-FE pigs, which may indicate that these animals are more efficient in conserving resources that can be utilised for other important biological processes. Shifts in carbohydrate conversion into glucose in FE-divergent muscle may underpin the altered evolution of $\mathrm{pH}$ profile in meat from the divergent groups. Although muscle depth did not significantly differ between the FE groups, our transcriptomic findings indicate that altered amino acid metabolism and increased mobilisation \& flux of calcium may influence, at least to some extent, growth in FE-divergent muscle. Moreover, decreased degradation of fibroblasts, the key players in the synthesis of the extracellular matrix, could impact on collagen turnover and alter tenderness of meat. Biological functions important in metabolism of lipids were also affected by FE. Specifically, enhanced lipid degradation in more efficient pigs may potentially underlie a more efficient fat metabolism in these animals.

\section{Materials and Methods}

Animals and experimental design

Animal housing, diets and tests were previously described in details in Metzler-Zebeli and colleagues [81]. 138 pigs from the intact litters of 12 sows (Landrace $\mathrm{x}$ Large White; Hermitage Genetics, Kilkenny, Ireland) inseminated with semen from 6 boars (Maxgro; Hermitage Genetics; 2 litters per boar, each having a high estimated breeding value for FE), were utilised in this study. Pigs, weaned at 28 days of age and group-housed (entire sibling groups), were provided with ad libitum access to feed and water. Diets were provided in the same sequence with the same ingredient and chemical composition (starter, link, weaner and finisher) and were delivered to pigs via Feed Intake Recording Equipment (FIRE) feeders (Schauer Agrotonic, Wels, Austria). Pigs were tested from day 42 until 91 post-weaning. Feed intake was recorded daily, whereas pig weight, back-fat depth and muscle depth were recorded weekly between day 70 and day 120 of age. Average daily feed intake (ADFI) and average daily gain (ADG) were calculated for each pig weekly. Residual feed intake (RFI, a measure of FE defined as the difference between actual feed intake and predicted feed requirements) was calculated after day 120 of age as the residual from a least squares regression model of ADFI on ADG, metabolic live weight, gender and also all relevant two-way interactions, and the effects of back-fat and muscle depth using the PROC REG procedure in SAS (version 9.4; SAS Inst. Inc., Cary, NC, USA). Based on RFI values, pigs were categorised within litter and gender as low (L) RFI and high (H) RFI and of these a total of 40 (20 extremes from LRFI (high-FE) - 10 males and 10 females, and 20 extremes from HRFI (low-FE) - 10 males and 10 females) were selected for gene expression profiling and meat quality analysis. The mean RFI (g/day) of the LRFI and HRFI pigs was -100.2 (SD: 97.9) and 150.7 (SD: 163.3) respectively, whereas the mean of feed conversion ratio (FCR, ratio of feed intake and weigh gain) of the LRFI 


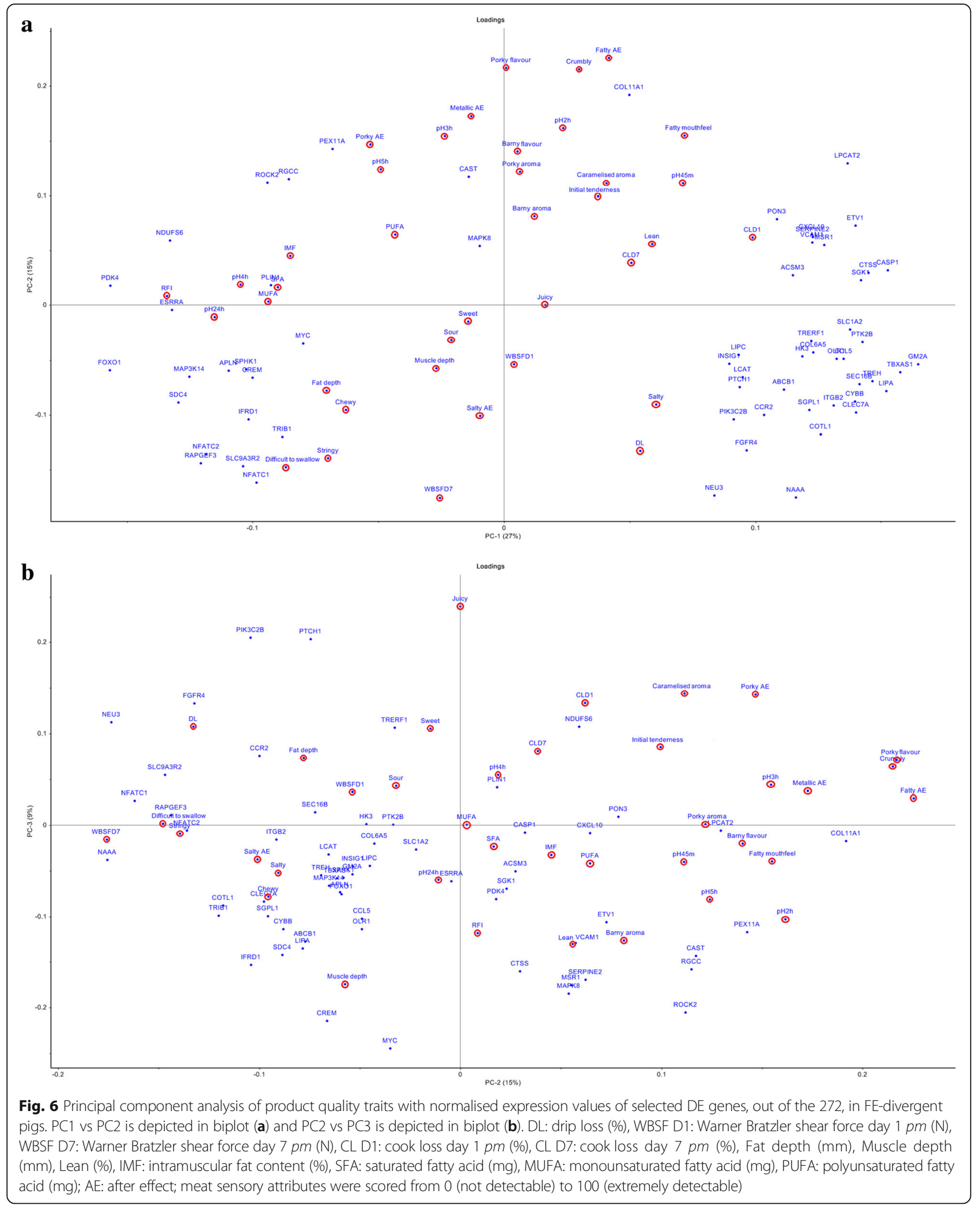

(high-FE) and HRFI (low-FE) pigs was 1.98 (SD: 0.16) and 2.27 (SD: 0.25) respectively. The slaughter of animals, fasted for 18 hours with an average final body weight of $99 \mathrm{~kg}$ (SD: $11.4 \mathrm{~kg}$ ), occurred on 2 slaughter days, a week apart, and was by electronic stunning followed by exsanguination. Samples of the LTL muscle 
were collected and snap frozen in liquid nitrogen within 10 minutes $p m$ followed by storage at $-80^{\circ} \mathrm{C}$ until RNA isolation. The LTL muscle was excised 24 hours pm from each carcass and utilised for meat quality analysis.

\section{RNA library preparation, differential expression analysis and functional annotation}

Sixteen muscle samples selected from the most FE-divergent siblings of the same gender ( 8 from LRFI (high-FE) - 4 males and 4 females, and 8 from HRFI (low-FE) - 4 males and 4 females), were snap frozen following which they were ground into fine powder in liquid nitrogen. Total RNA was isolated using Tri-Reagent (Sigma-Alrich, Taufkirchen, Germany), followed by DNase treatment and a column-based purification using the Nucleospin RNA II kit (Macherey-Nagel, Düren, Germany). RNA library preparation was carried out using the TruSeq Stranded mRNA protocol. Following RNA sequencing with Illumina HiSeq2500, paired-end reads were mapped to the reference Sscrofa10.2 (Ensembl release 84) [82] using TopHat (2.1.0). Read counts were assigned to the gene features using the HTSeq 0.6.1 program [83]. Differential gene expression analysis in relation to FE was performed using DESeq2 package (3.4.0, https://www.r-project.org), including RFI groups and sow as fixed effects. Gene symbols for significantly altered genes $(P<0.01)$ and related fold changes were submitted to Ingenuity Pathway Analysis (IPA; Ingenuity Systems, http://www.ingenuity.com), whereby Benjamini-Hochberg (B-H) corrected $P$-values were used to detect significantly enriched bio-functions and canonical pathways $(P<0.01)$. Functional annotations with a $\mathrm{z}$-score greater than 2 and lower than -2 were considered significantly activated and inhibited in high-FE pigs, respectively. Information enclosed in the Ingenuity ${ }^{\circ}$ Knowledge Base was utilised to generate potential important interaction networks amongst the $\mathrm{DE}$ genes.

\section{Validation of RNA sequencing results}

For cDNA synthesis, $1 \mu \mathrm{g}$ of total RNA was utilized in the presence of random primers (Promega, Mannheim, Germany), oligo (dT) primer and Superscript ${ }^{\circ}$ III reverse transcriptase (Invitrogen Corp., San Diego, CA, USA). Thirteen DE genes were selected for validation through quantitative real-time PCR (qPCR). Primers for target genes (Additional file 4: Table S4) were designed using Primer-BLAST software in the NCBI (https://www. ncbi.nlm.nih.gov/tools/primer-blast) based on Sus scrofa nucleotide sequences and their specificity was determined with the BLAST search tool database (http://www. ncbi.nlm.nih.gov/BLAST). qPCR was carried out with LightCycler 96 system (Roche Mannheim, Germany). $2 \mu \mathrm{l}$ of cDNA was amplified in a $10 \mu \mathrm{l}$ reaction volume using 6 $\mu \mathrm{l}$ SYBR Green I Master (Roche) and $0.6 \mu \mathrm{l}(10 \mu \mathrm{M})$ of each forward and reverse primer. Cycling conditions for reference and $\mathrm{DE}$ genes consisted of initial denaturation at $95{ }^{\circ} \mathrm{C}$ for $5 \mathrm{~min}$ and 45 cycles of amplification $\left(95^{\circ} \mathrm{C}\right.$ for $10 \mathrm{sec}, 60^{\circ} \mathrm{C}$ for $15 \mathrm{sec}$ and $72{ }^{\circ} \mathrm{C}$ for $25 \mathrm{sec}$ ). A melting curve analysis was included at the end of the amplification to confirm the specificity of all amplification reactions. Normalised qPCR data were analysed using ANOVA test in R, including RFI groups as a fixed effect and sow as a random effect. Correlation analysis between the RNA-seq and $\mathrm{qPCR}$ data were carried out with $\mathrm{R}$ package considering the results as significant at $P<0.05$.

\section{Product quality}

Carcass grading along with technological and sensory meat quality traits as well as nutritional profiling of meat were measured using methods as described in detail by Horodyska and colleagues [14]. The carcass grading included fat depth, muscle depth, lean percent and IMF content, whilst the technological meat quality included $\mathrm{pH}$ (45m, 2h, 3h, 4h, 5h and 24h pm), drip loss, cook loss and tenderness (WBSF). Fatty acids were profiled to assess the nutritive value of meat. PROC MIXED procedure in the SAS system was used to evaluate associations between FE and meat quality traits in the Maxgro $\mathrm{x}$ (Landrace $\mathrm{x}$ Large White) pigs $(n=40)$. The model included RFI groups, gender \& slaughter day as fixed effects, sow as a random effect, live weight as a covariate and the absolute values of RFI as a weight statement. Moreover, Spearman's correlations ( $r$ ) as well as principal component analysis of product quality / sensory traits / nutritive value and normalised expression values of selected DE genes, out of a total number of identified DE genes in RFI-divergent pigs $(n=16)$, were determined using the PROC CORR procedure in the SAS system (version 9.4) and Unscrambler software (version 10.3; CAMO software, Oslo, Norway), respectively.

\section{Additional files}

Additional file 1: Table S1. Differentially expressed transcripts $(n=272)$ at a $P<0.01$ between high-FE and low-FE groups. (XLSX $29 \mathrm{~kb}$ )

Additional file 2: Table S2. Biological functions significantly enriched with differentially expressed genes, including a list of sub-categories contained within each function. (XLSX $18 \mathrm{~kb}$ )

Additional file 3: Table S3. All canonical pathways significantly enriched with differentially expressed genes. (XLSX $12 \mathrm{~kb}$ )

Additional file 4: Table S4. Forward and reverse primers for RNA-seq validation through qPCR. (DOCX $16 \mathrm{~kb})$

\section{Abbreviations}

FE: Feed efficiency; RFI: Residual feed intake; LTL: Longissimus thoracis et lumborum; IMF: Intramuscular fat content; pm: post-mortem; LRFI: Low RFI; HRFI: High RFI; WBSF: Warner Bratzler shear force; SFA: Saturated fatty acids; MUFA: Monounsaturated fatty acids; PUFA: Polyunsaturated fatty acids 


\section{Acknowledgements}

The authors wish to thank Carol Griffin for training sensory panellists and conducting sensory assessment of the samples, and Dr. Gonzalo DelgadoPando for participating in the principal component analysis. The authors also thank Angela Garve for her excellent technical help, as well as staff and students at Teagasc who assisted in animal sampling.

\section{Funding}

The ECO-FCE project was funded by the European Union Seventh Framework Programme (FP7 2007/2013) under grant agreement No. 311794.

\section{Availability of data and materials}

Raw RNA-seq data were deposited in the ArrayExpress database at EMBL-EBI (https://www.ebi.ac.uk/arrayexpress/experiments/E-MTAB-6174/).

\section{Authors' contributions}

JH collected samples, extracted RNA, prepared libraries, validated RNA-seq via $\mathrm{qPCR}$, measured meat quality traits, carried out data analysis and wrote the manuscript; KW designed the experiment and edited the manuscript; HR participated in statistical analysis and edited the manuscript; NT assisted in library preparation, performed RNA-seq and data analysis, and edited the manuscript; AMM participated in animal sampling and edited the manuscript; PGL provided the animals, participated in data collection and analysis, and edited the manuscript; RMH conceived and designed the experiment, collected samples and edited the manuscript. All authors read and approved the final manuscript.

\section{Ethics approval}

In this study, all procedures were conducted in accordance with national regulations concerning animal research and commercial slaughtering under experimental licence from the Irish Department of Health in accordance with the Cruelty to Animals Act 1876 and the European Communities (Amendments of the cruelty of Animals Act 1976) Regulations, 1994, and were authorized by Teagasc Animal Ethics Committee.

\section{Consent for publication}

Not applicable

\section{Competing interests}

The authors declare that they have no competing interests.

\section{Publisher's Note}

Springer Nature remains neutral with regard to jurisdictional claims in published maps and institutional affiliations.

\section{Author details}

${ }^{1}$ Teagasc, Food Research Centre, Ashtown, Dublin 15, Ireland. ${ }^{2}$ Leibniz Institute for Farm Animal Biology (FBN), Institute for Genome Biology, Dummerstorf, Germany. ${ }^{3}$ Faculty of Agricultural and Environmental Sciences, University Rostock, Rostock, Germany. ${ }^{4}$ Teagasc, Pig Development Department, AGRIC, Moorepark, Fermoy, Co. Cork, Ireland.

Received: 1 December 2017 Accepted: 16 October 2018 Published online: 01 November 2018

\section{References}

1. The Food and Agriculture Organization of the United Nations: Sources of meat. 2014. [http://www.fao.org/ag/againfo/themes/en/meat/backgr_ sources.html]. Accessed 30 Sept 2017.

2. Hathwar SC, Rai AK, Modi VK, Narayan B. Characteristics and consumer acceptance of healthier meat and meat product formulations - a review. J Food Sci Technol. 2012;49(6):653-64

3. Micha R, Michas G, Mozaffarian D. Unprocessed red and processed meats and risk of coronary artery disease and type 2 diabetes - an updated review of the evidence. Curr Atheroscler Rep. 2012;14(6):515-24.

4. Wang Y, Beydoun MA. Meat consumption is associated with obesity and central obesity among US adults. Int J Obes (2005). 2009;33(6):621-8.

5. Cordts A, Nitzko S, Spiller A. Consumer response to negative information on meat consumption in germany. IFAMA. 2014;17(A):83-106.

6. McNeill SH. Inclusion of red meat in healthful dietary patterns. Meat Sci. 2014;98(3):452-60.
7. Wilkinson JM. Re-defining efficiency of feed use by livestock. Animal. 2011; 5(7):1014-22.

8. Patience JF, Rossoni-Serão MC, Gutiérrez NA. A review of feed efficiency in swine: biology and application. J Anim Sci Biotechnol. 2015;6(1):33.

9. Tizioto PC, Coutinho LL, Oliveira PSN, Cesar ASM, Diniz WJS, Lima AO, Rocha MI, Decker JE, Schnabel RD, Mourao GB, et al. Gene expression differences in Longissimus muscle of Nelore steers genetically divergent for residual feed intake. Sci Rep. 2016;6:39493.

10. Morales PE, Bucarey JL, Espinosa A. Muscle lipid letabolism: role of lipid droplets and perilipins. J Diabetes Res. 2017;2017:1789395.

11. Pedersen BK. Muscle as a secretory organ. Compr Physiol. 2013;3(3):1337-62.

12. Turner N, Cooney GJ, Kraegen EW, Bruce CR. Fatty acid metabolism, energy expenditure and insulin resistance in muscle. J Endocrinol. 2014;220(2):T61-79.

13. Faure J, Lefaucheur L, Bonhomme N, Ecolan P, Meteau K, Coustard SM, Kouba M, Gilbert H, Lebret B. Consequences of divergent selection for residual feed intake in pigs on muscle energy metabolism and meat quality. Meat Sci. 2013;93(1):37-45.

14. Horodyska J, Oster M, Reyer H, Mullen AM, Lawlor PG, Wimmers K, Hamill RM. Analysis of meat quality traits and gene expression profiling of pigs divergent in residual feed intake. Meat Sci. 2018;137:265-74.

15. Czernichow S, Thomas D, Bruckert E. n-6 Fatty acids and cardiovascular health: a review of the evidence for dietary intake recommendations. $\mathrm{Br} J$ Nutr. 2010;104(6):788-96.

16. Lefaucheur L, Lebret B, Ecolan P, Louveau I, Damon M, Prunier A, Billon Y, Sellier $\mathrm{P}$, Gilbert $\mathrm{H}$. Muscle characteristics and meat quality traits are affected by divergent selection on residual feed intake in pigs. J Anim Sci. 2011; 89(4):996-1010.

17. Smith RM, Gabler NK, Young JM, Cai W, Boddicker NJ, Anderson MJ, HuffLonergan E, Dekkers JC, Lonergan SM. Effects of selection for decreased residual feed intake on composition and quality of fresh pork. J Anim Sci. 2011;89(1):192-200.

18. Gondret F, Vincent A, Houee-Bigot M, Siegel A, Lagarrigue S, Causeur D, Gilbert H, Louveau I. A transcriptome multi-tissue analysis identifies biological pathways and genes associated with variations in feed efficiency of growing pigs. BMC Genomics. 2017;18(1):244.

19. Jing L, Hou Y, Wu H, Miao YX, Li XY, Cao JH, Brameld JM, Parr T, Zhao SH, Transcriptome analysis of mRNA and miRNA in skeletal muscle indicates an important network for differential Residual Feed Intake in pigs. Sci Rep. 2015;5:11953.

20. Vincent A, Louveau I, Gondret F, Trefeu C, Gilbert H, Lefaucheur L. Divergent selection for residual feed intake affects the transcriptomic and proteomic profiles of pig skeletal muscle. J Anim Sci. 2015;93(6):2745-58.

21. Clapperton M, Bishop SC, Glass EJ. Selection for lean growth and food intake leads to correlated changes in innate immune traits in Large White pigs. Anim Sci. 2006;82:867-76.

22. Adler M, Murani E, Ponsuksili S, Wimmers K. PBMC transcription profiles of pigs with divergent humoral immune responses and lean growth performance. Int J Biol Sci. 2013;9(9):907-16.

23. Schaeffer EM, Yap GS, Lewis CM, Czar MJ, McVicar DW, Cheever AW, Sher A, Schwartzberg PL. Mutation of Tec family kinases alters Thelper cell differentiation. Nat Immunol. 2001;2(12):1183-8.

24. Okkenhaug K. Signalling by the phosphoinositide 3-kinase family in immune cells. Annu Rev Immunol. 2013;31:675-704.

25. Srivastava S, Di L, Zhdanova O, Li Z, Vardhana S, Wan Q, Yan Y, Varma R, Backer J, Wulff $\mathrm{H}$, et al. The class II Phosphatidylinositol 3 kinase C2 $\beta$ is required for the activation of the $\mathrm{K}(+)$ channel KCa3.1 and CD4 T-Cells. Mol Biol Cell. 2009;20(17):3783-91.

26. Jundi K, Greene CM. Transcription of Interleukin-8: How Altered Regulation Can Affect Cystic Fibrosis Lung Disease. Biomolecules. 2015;5(3):1386-98.

27. Sato T, Hongu T, Sakamoto M, Funakoshi Y, Kanaho Y. Molecular mechanisms of N-Formyl-methionyl-leucyl-phenylalanine-induced superoxide generation and degranulation in mouse neutrophils: phospholipase $\mathrm{D}$ is dispensable. Mol Cell Biol. 2013;33(1):136-45.

28. MacMicking J, Xie QW, Nathan C. Nitric oxide and macrophage function. Annu Rev Immunol. 1997;15:323-50.

29. Weber KL, Welly BT, Van Eenennaam AL, Young AE, Porto-Neto LR, Reverter A, Rincon G. Identification of gene networks for residual feed intake in angus cattle using genomic prediction and RNA-seq. PLoS One. 2016;11(3): e0152274.

30. Leshchinsky TV, Klasing KC. Divergence of the inflammatory response in two types of chickens. Dev Comp Immunol. 2001;25(7):629-38. 
31. Da Conceicao Neta ER, Johanningsmeier SD, Drake MA, McFeeters RF. A chemical basis for sour taste perception of acid solutions and fresh-pack dill pickles. J Food Sci. 2007;72(6):S352-9.

32. Ramos Da Conceicao Neta ER, Johanningsmeier SD, McFeeters RF. The chemistry and physiology of sour taste--a review. J Food Sci. 2007;72(2): R33-8.

33. Lipinski K, Stasiewicz M, Purwin C, Zuk-Golaszewska K. Effects of magnesium on pork quality. J Elementol. 2011;16(2):325-37.

34. Beauclercq S, Hennequet-Antier C, Praud C, Godet E, Collin A, Tesseraud S, Metayer-Coustard S, Bourin M, Moroldo M, Martins F, et al. Muscle transcriptome analysis reveals molecular pathways and biomarkers involved in extreme ultimate $\mathrm{pH}$ and meat defect occurrence in chicken. Sci Rep. 2017;7(1):6447.

35. Sode K, Akaike E, Sugiura H, Tsugawa W. Enzymatic synthesis of a novel trehalose derivative, 3,3'-diketotrehalose, and its potential application as the trehalase enzyme inhibitor. FEBS Lett. 2001;489(1):42-5.

36. Pösö AR, Puolanne E. Carbohydrate metabolism in meat animals. Meat Sci. 2005;70(3):423-34.

37. Silva JA, Patarata L, Martins C. Influence of ultimate $\mathrm{pH}$ on bovine meat tenderness during ageing. Meat Sci. 1999;52(4):453-9.

38. Ciobanu DC, Bastiaansen JW, Lonergan SM, Thomsen H, Dekkers JC, Plastow GS, Rothschild MF. New alleles in calpastatin gene are associated with meat quality traits in pigs. J Anim Sci. 2004;82(10):2829-39.

39. Evan Gl, Wyllie AH, Gilbert CS, Littlewood TD, Land H, Brooks M, Waters CM, Penn LZ, Hancock DC. Induction of apoptosis in fibroblasts by c-myc protein. Cell. 1992;69(1):119-28.

40. Oh JD, Kim ES, Lee HK, Song KD. Effect of a c-MYC gene polymorphism (g. $3350 \mathrm{G}>\mathrm{C}$ ) on meat quality traits in berkshire. Asian-Australas J Anim Sci. 2015:28(11):1545-50.

41. Velleman SG, Coy CS, McFarland DC. Effect of syndecan-1, syndecan-4, and glypican-1 on turkey muscle satellite cell proliferation, differentiation, and responsiveness to fibroblast growth factor 2. Poult Sci. 2007;86(7):1406-13.

42. Shin J, McFarland DC, Velleman SG. Heparan sulfate proteoglycans, syndecan-4 and glypican-1, differentially regulate myogenic regulatory transcription factors and paired box 7 expression during turkey satellite cell myogenesis: implications for muscle growth. Poult Sci. 2012;91(1):201-7.

43. Ronning SB, Carlson CR, Stang E, Kolset SO, Hollung K, Pedersen ME. Syndecan-4 regulates muscle differentiation and is internalized from the plasma membrane during myogenesis. PLoS One. 2015;10(6):e0129288.

44. Nwadozi E, Roudier E, Rullman E, Gustafsson T, Haas T. Endothelial FoxO proteins regulate obesity associated skeletal muscle capillary rarefaction. Faseb J. 2015;29:630-10.

45. Kamei Y, Miura S, Suzuki M, Kai Y, Mizukami J, Taniguchi T, Mochida K, Hata T, Matsuda J, Aburatani H, et al. Skeletal muscle FOXO1 (FKHR) transgenic mice have less skeletal muscle mass, down-regulated type I (slow twitch/ red muscle) fiber genes, and impaired glycemic control. J Biol Chem. 2004; 279(39):41114-23.

46. Przybylski RJ, Szigeti V, Davidheiser S, Kirby AC. Calcium regulation of skeletal myogenesis. II. Extracellular and cell surface effects. Cell Calcium. 1994;15(2):132-42.

47. Tu MK, Levin JB, Hamilton AM, Borodinsky LN. Calcium signaling in skeletal muscle development, maintenance and regeneration. Cell Calcium. 2016; 59(2-3):91-7.

48. Tizioto PC, Gromboni CF, Nogueira AR, de Souza MM, Mudadu Mde A, Tholon P, Rosa Ado N, Tullio RR, Medeiros SR, Nassu RT, et al. Calcium and potassium content in beef: influences on tenderness and associations with molecular markers in Nellore cattle. Meat Sci. 2014;96(1):436-40.

49. Wang H, Ji Y, Wu G, Sun K, Sun Y, Li W, Wang B, He B, Zhang Q, Dai Z, et al. I-Tryptophan activates mammalian target of rapamycin and enhances expression of tight junction proteins in intestinalporcine epithelial cells. J Nutr. 2015;145(6):1156-62.

50. Afonso J, Tizioto PC, Oliveira PSN, Diniz WJS, Lima AOD, Souza MMD, Rocha MIP, Silva JVD, Buss CE, Gromboni CF, et al. 0903 Differentially expressed genes in genetically divergent Nellore steers for calcium content in the Longissimus dorsi muscle. J Anim Sci. 2016;94:435.

51. Ramayo-Caldas Y, Renand G, Ballester M, Saintilan R, Rocha D. Multi-breed and multi-trait co-association analysis of meat tenderness and other meat quality traits in three French beef cattle breeds. Genet Sel Evol. 2016;48(1):37

52. Hamill RM, McBryan J, McGee C, Mullen AM, Sweeney T, Talbot A, Cairns MT, Davey GC. Functional analysis of muscle gene expression profiles associated with tenderness and intramuscular fat content in pork. Meat Sci. 2012;92(4):440-50.

53. Ouali A, Gagaoua M, Boudida Y, Becila S, Boudjellal A, Herrera-Mendez CH, Sentandreu MA. Biomarkers of meat tenderness: Present knowledge and perspectives in regards to our current understanding of the mechanisms involved. Meat Sci. 2013:95(4):854-70.

54. Ouali A, Herrera-Mendez CH, Coulis G, Becila S, Boudjellal A, Aubry L, Sentandreu MA. Revisiting the conversion of muscle into meat and the underlying mechanisms. Meat Sci. 2006;74(1):44-58.

55. Scherzer MT, Waigel S, Donninger $H$, Arumugam $V$, Zacharias W, Clark G, Siskind L, Soucy P, Beverly L. Fibroblast-derived extracellular matrices: an alternative cell culture system that increases metastatic cellular properties. PLoS One. 2015;10(9):e0138065.

56. Russell SB, Russell JD, Trupin KM. Collagen synthesis in human fibroblasts: effects of ascorbic acid and regulation by hydrocortisone. J Cell Physiol. 1981;109(1):121-31.

57. Neal JW, Clipstone NA. A constitutively active NFATC1 mutant induces a transformed phenotype in 3T3-L1 fibroblasts. J Biol Chem. 2003;278(19): $17246-54$.

58. Robbs BK, Cruz AL, Werneck MB, Mognol GP, Viola JP. Dual roles for NFAT transcription factor genes as oncogenes and tumor suppressors. Mol Cell Biol. 2008;28(23):7168-81.

59. Tsuboi K, Sun YX, Okamoto Y, Araki N, Tonai T, Ueda N. Molecular characterization of $\mathrm{N}$-acylethanolamine-hydrolyzing acid amidase, a novel member of the choloylglycine hydrolase family with structural and functional similarity to acid ceramidase. J Biol Chem. 2005;280(12): 11082-92.

60. Sikora J, Dworski S, Jones EE, Kamani MA, Micsenyi MC, Sawada T, Le Faouder P, Bertrand-Michel J, Dupuy A, Dunn CK, et al. Acid ceramidase deficiency in mice results in a broad range of central nervous system abnormalities. Am J Pathol. 2017;187(4):864-83.

61. Shimokomaki $m$, Elsden dF, Bailey aJ. Meat tenderness: age related changes in bovine intramuscular collagen. J Food Sci. 1972;37(6):892-6.

62. Garg J, Feng YX, Jansen SR, Friedrich J, Lezoualc'h F, Schmidt M, Wieland T. Catecholamines facilitate VEGF-dependent angiogenesis via beta2-adrenoceptorinduced Epac1 and PKA activation. Oncotarget. 2017:8(27):44732-48.

63. Casas E, White SN, Wheeler TL, Shackelford SD, Koohmaraie M, Riley DG, Chase CC Jr, Johnson DD, Smith TP. Effects of calpastatin and micro-calpain markers in beef cattle on tenderness traits. J Anim Sci. 2006;84(3):520-5.

64. Costello S, O'Doherty E, Troy DJ, Ernst CW, Kim KS, Stapleton P, Sweeney T, Mullen AM. Association of polymorphisms in the calpain I, calpain II and growth hormone genes with tenderness in bovine M. longissimus dorsi. Meat Sci. 2007:75(4):551-7.

65. Page BT, Casas E, Heaton MP, Cullen NG, Hyndman DL, Morris CA, Crawford AM, Wheeler TL, Koohmaraie M, Keele JW, et al. Evaluation of singlenucleotide polymorphisms in CAPN1 for association with meat tenderness in cattle. J Anim Sci. 2002:80(12):3077-85.

66. Schenkel FS, Miller SP, Jiang Z, Mandell IB, Ye X, Li H, Wilton JW. Association of a single nucleotide polymorphism in the calpastatin gene with carcass and meat quality traits of beef cattle. J Anim Sci. 2006;84(2):291-9.

67. Kasprzyk A, Tyra M, Babicz M. Fatty acid profile of pork from a local and a commercial breed. Arch Anim Breed. 2015;58(2):379-85.

68. Wood JD, Enser M, Fisher AV, Nute GR, Sheard PR, Richardson RI, Hughes SI, Whittington FM. Fat deposition, fatty acid composition and meat quality: A review. Meat Sci. 2008:78(4):343-58.

69. Austin MA. Triacylglycerol and coronary heart disease. Proc Nutr Soc. 1997; 56(2):667-70.

70. Athyros VG, Kakafika Al, Papageorgiou AA, Tziomalos K, Skaperdas A, Pagourelias E, Pirpasopoulou A, Karagiannis A, Mikhailidis DP. Atorvastatin decreases triacylglycerol-associated risk of vascular events in coronary heart disease patients. Lipids. 2007:42(11):999-1009.

71. Dominguez R, Lorenzo JM. Effect of genotype on fatty acid composition of intramuscular and subcutaneous fat of Celta pig breed. Grasas Y Aceites. 2014;65(3):037.

72. Dugan MER, Vahmani P, Turner TD, Mapiye C, Juárez M, Prieto N, Beaulieu AD, Zijlstra RT, Patience JF, Aalhus JL. Pork as a source of omega-3 (n-3) fatty acids. J Clin Med. 2015;4(12):1999-2011.

73. Moisá SJ, Shike DW, Faulkner DB, Meteer WT, Keisler D, Loor JJ. Central role of the PPARY gene network in coordinating beef cattle intramuscular adipogenesis in response to weaning age and nutrition. Gene Regul Syst Bio. 2014;8:17-32. 
74. Huang W, Zhang X, Li A, Xie L, Miao X. Differential regulation of mRNAs and IncRNAs related to lipid metabolism in two pig breeds. Oncotarget. 2017; 8(50):87539-53.

75. Li B, Weng Q, Dong C, Zhang Z, Li R, Liu J, Jiang A, Li Q, Jia C, Wu W, et al. A key gene, PLIN1, can affect porcine intramuscular fat content based on transcriptome analysis. Genes. 2018;9(4):E194.

76. Lim D, Lee SH, Kim NK, Cho YM, Chai HH, Seong HH, Kim H. Gene coexpression analysis to characterize genes related to marbling trait in hanwoo (Korean) cattle. Asian-Australas J Anim Sci. 2013;26(1):19-29.

77. Getz GS, Reardon CA. Paraoxonase, a cardioprotective enzyme: continuing issues. Curr Opin Lipidol. 2004;15(3):261-7.

78. Feingold KR, Grunfeld C. Introduction to lipids and lipoproteins. In: De Groot $\sqcup$, Chrousos G, Dungan K, et al., editors. . South Dartmouth (MA): MDText. com, Inc.; 2000. Available from: https://www.ncbi.nlm.nih.gov/books/ NBK305896/.

79. Shih DM, Yu JM, Vergnes L, Dali-Youcef N, Champion MD, Devarajan A, Zhang P, Castellani LW, Brindley DN, Jamey C, et al. PON3 knockout mice are susceptible to obesity, gallstone formation, and atherosclerosis. FASEB J. 2015;29(4):1185-97.

80. Chatterjee C, Sparks DL. Hepatic lipase, high density lipoproteins, and hypertriglyceridemia. Am J Pathol. 2011;178(4):1429-33.

81. Metzler-Zebeli BU, Lawlor PG, Magowan E, McCormack UM, Curiao T, Hollmann M, Ertl R, Aschenbach JR, Zebeli Q. Finishing pigs that are divergent in feed efficiency show small differences in intestinal functionality and structure. PLoS One. 2017;12(4):e0174917.

82. Kim D, Pertea G, Trapnell C, Pimentel H, Kelley R, Salzberg SL. TopHat2: accurate alignment of transcriptomes in the presence of insertions. deletions and gene fusions. Genome Biol. 2013;14(4):R36.

83. Anders S, Pyl PT, Huber W. HTSeq-a Python framework to work with highthroughput sequencing data. Bioinformatics. 2015;31(2):166-9.

Ready to submit your research? Choose BMC and benefit from:

- fast, convenient online submission

- thorough peer review by experienced researchers in your field

- rapid publication on acceptance

- support for research data, including large and complex data types

- gold Open Access which fosters wider collaboration and increased citations

- maximum visibility for your research: over $100 \mathrm{M}$ website views per year

At $\mathrm{BMC}$, research is always in progress.

Learn more biomedcentral.com/submissions 